\title{
Progesterone metabolites in breast cancer
}

\author{
John P Wiebe
}

Department of Biology, Hormonal Regulatory Mechanisms Laboratory, University of Western Ontario, London, Ontario, Canada N6A 5B7

(Requests for offprints should be addressed to J P Wiebe; Email: jwiebe@ uwo.ca)

\begin{abstract}
In the 70 years since progesterone $(\mathrm{P})$ was identified in corpus luteum extracts, its metabolism has been examined extensively in many tissues and cell lines from numerous species. In addition to the reproductive tissues and adrenals, every other tissue that has been investigated appears to have one or more P-metabolizing enzyme, each of which is specific for a particular site on the P molecule. In the past, the actions of the $P$ metabolizing enzymes generally have been equated to a means of reducing the $\mathrm{P}$ concentration in the tissue microenvironment, and the products have been dismissed as inactive waste metabolites. In human breast tissues and cell lines, the following P-metabolizing enzymes have been identified: $5 \alpha$-reductase, $3 \alpha$-hydroxysteroid oxidoreductase ( $3 \alpha-\mathrm{HSO}), 3 \beta-\mathrm{HSO}$, $20 \alpha-\mathrm{HSO}$, and $6 \alpha$-hydroxylase. Rather than providing diverse pathways for inactivating and controlling the concentration of $\mathrm{P}$ in breast tissue microenvironments, it is proposed that the enzymes act directly on $\mathrm{P}$ to produce two types of autocrines/paracrines with opposing regulatory roles in breast cancer. Evidence is reviewed which shows that $P$ is directly converted to the 4-pregnenes, $3 \alpha-$

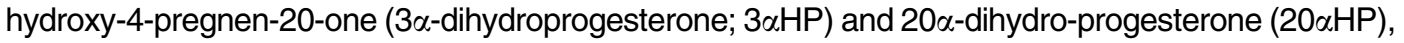
by the actions of $3 \alpha-\mathrm{HSO}$ and $20 \alpha$-HSO respectively and to the $5 \alpha$-pregnane, $5 \alpha$-pregnane-3,20dione( $5 \alpha$-dihydroprogesterone; $5 \alpha \mathrm{P}$ ), by the irreversible action of $5 \alpha$-reductase. In vitro studies on a number of breast cell lines indicate that $3 \alpha \mathrm{HP}$ promotes normalcy by downregulating cell proliferation and detachment, whereas $5 \alpha \mathrm{P}$ promotes mitogenesis and metastasis by stimulating cell proliferation and detachment. The hormones bind to novel, separate, and specific plasma membrane-based receptors and influence opposing actions on mitosis, apoptosis, and cytoskeletal and adhesion plaque molecules via cell signaling pathways. In normal tissue, the ratio of 4-pregnenes:5 $\alpha$ pregnanes is high because of high P $3 \alpha$ - and $20 \alpha$-HSO activities/expression and low P $5 \alpha$-reductase activity/expression. In breast tumor tissue and tumorigenic cell lines, the ratio is reversed in favor of the $5 \alpha$-pregnanes because of altered P-metabolizing enzyme activities/expression. The evidence suggests that the promotion of breast cancer is related to changes in in situ concentrations of cancerinhibiting and -promoting P metabolites. Current estrogen-based theories and therapies apply to only a fraction of all breast cancers; the majority (about two-thirds) of breast cancer cases are estrogeninsensitive and have lacked endocrine explanations. As the P metabolites, $5 \alpha \mathrm{P}$ and $3 \alpha \mathrm{HP}$, have been shown to act with equal efficacy on all breast cell lines tested, regardless of their tumorigenicity, estrogen sensitivity, and estrogen receptor/progesterone receptor status, it is proposed that they offer a new hormonal basis for all forms of breast cancer. New diagnostic and therapeutic possibilities for breast cancer progression, control, regression, and prevention are suggested.
\end{abstract}

Endocrine-Related Cancer (2006) 13 717-738

\section{Introduction}

The name 'progesterone' was first adopted in 1935 (Allen 1970), shortly after it was isolated from corpus luteum extracts (Allen \& Corner 1929), purified (Allen 1930, Slotta et al. 1934), and structurally identified (Butenandt 1934). In the 70 years since its discovery, nearly 100000 papers have been published dealing with progesterone P; (4-pregnene-3,20-dione) on many levels. As the name implies, its main actions have been linked primarily to human female reproductive aspects involving the uterine changes associated with the menstrual cycle and gestation. However, $\mathrm{P}$ is now known to influence (directly or indirectly) many other tissues and facets of regulatory physiology and endocrinology, including those of the mammary glands. Soon after its discovery, the metabolism of 
$\mathrm{P}$ began to be investigated, primarily with the aim of determining its route of inactivation. It has become apparent that many tissues have P-metabolizing enzymes, which can modify different parts of the molecule. Although the resulting metabolites have been shown, in some tissues, to be active molecules in and of themselves, for the most part there has been a reluctance to accept them as anything other than waste products, with their formation as a means of decreasing the local P concentrations.

PR has long been linked to the proliferative changes in the normal breast, but its role in breast cancer is unclear. Recent studies have provided evidence that $P$ metabolites formed in breast tissue have regulatory functions with respect to breast cancer that may previously have been attributed to P. We first suggested (Wiebe et al. 2000) that the $\mathrm{P}$ metabolites produced within breast tissues might be independently active hormones functioning as cancerpromoting or -inhibiting regulatory agents. By this hypothesis, the maintenance of normalcy or progression to neoplasia would depend on the ratios of pro- to anticancer $\mathrm{P}$ metabolites in the local breast tissue microenvironment.

The aim of this review is to summarize observations which indicate that most (if not all) tissues/cells may have some capacity to convert $\mathrm{P}$ and that mammary tissue in particular has enzymes which catalyze the direct conversion of $\mathrm{P}$ to two classes of active metabolites. Evidence is reviewed that these $\mathrm{P}$ metabolites function as independent proor anti-cancer autocrine/paracrine hormones that regulate cell proliferation, adhesion, apoptosis and cytoskeletal, and other cell status molecules via novel receptors located in the cell membrane and intrinsically linked to cell signaling pathways. Current endocrine therapies are based on suppressing estrogen levels or inhibiting its actions. Unfortunately, only a fraction of all breast cancer patients respond to this estrogen-based therapy and the response is only temporary (McGuire 1987). As the breast tissue $\mathrm{P}$ metabolites act on breast cell lines regardless of their tumorigenicity, estrogen sensitivity and estrogen receptor (ER) and progesterone receptor (PR) status, they are suggested to provide a new endocrine-based explanation for progression to the various forms of breast cancer as well as for the maintenance of normalcy in breast tissues. Based on the findings, it is proposed that in breast tissue $\mathrm{P}$ serves as a precursor for active steroid hormones whose relative concentrations determine the levels of mitogenic, apoptotic, and metastatic activities locally within the tissue.

\section{Progesterone is metabolized by many tissues}

Soon after its identification, a large number of studies followed to determine the metabolism of P. In the early decades, many workers in the field identified and measured urinary metabolites of $\mathrm{P}$ with the aim of ascertaining how the body inactivated this progestagen. By 1954, almost 100 naturally occurring steroids had been isolated from tissue and urinary sources (Dorfman 1954). The urinary $P$ derivatives were assumed to result from metabolism in the liver and included $5 \beta$-pregnanes

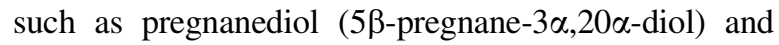
pregnanolone (5 5 -pregnan-3 $\alpha$-ol-20-one) as well as the $5 \alpha$-pregnanes, $5 \alpha$-pregnane-3,20-dione ( $5 \alpha \mathrm{P}), 5 \alpha$-pregnan-3 $\alpha$-ol-20-one, $5 \alpha$-pregnan-3 $\beta$-ol-20-one, and $5 \alpha$-pregnan3-3 $\alpha(\beta), 20 \alpha$-diols (Atherden 1959). The rapid metabolism of intravenously administered $\left[{ }^{14} \mathrm{C}\right]$ progesterone by eviscerated rats (Berliner \& Wiest 1956, Wiest 1956) in which tissues such as liver, spleen, gut, and adrenals had been removed, showed that $\mathrm{P}$ conversion was also occurring extrahepatically. It then soon became apparent that $\mathrm{P}$ serves as the precursor for the major steroid hormones (androgens, estrogens, corticosteroids) produced by the gonadal and adrenal cortical tissues.

A large number of metabolism studies on a variety of reproductive tissue from various species and physiological states showed that $\mathrm{P}$ is not only converted to the well-known steroid hormones such as estradiol and testosterone, but also to various 21-carbon derivatives for which there were no welldefined functions (Fig. 1). Studies on uterine tissues from rats (Marrone \& Karavolas 1981, 1982, Redmond \& Pepe 1986), guinea pigs (Glasier et al. 1994, Hobkirk et al. 1997), and humans (Bryson \& Sweat 1967, 1969, Pollow et al. 1975, Milewich et al. 1977, Arici et al. 1999), as well as placentae from humans (Little et al. 1959) and goats (Sheldrick et al. 1981), showed the presence of numerous P-converting enzymes. Similarly, incubations with ovarian tissues (especially granulosa cells) from rat (Zmigrod et al. 1972, Lacy et al. 1976, Nimrod 1977, de la Llosa-Hermier et al. 1983, Moon et al. 1986, 1987, Wiebe et al. 1994a), human (Sweat et al. 1960), and chicken (Marrone 1986, Wiebe et al. 1990), as well as incubations with testicular cells or homogenates from trout (Andersson \& Rafter 1990), frog (Canosa et al. 1998), mouse (Kuwata et al. 1976), rat (Slaunwhite \& Samuels 1956, Wiebe 1978, Wiebe \& Tilbe 1979, Wiebe et al. 1980, Tilbe \& Wiebe 1981), rabbit (Matsumoto et al. 1976), and human (Savard et al. 1956, Stegner \& Lisboa 1984), have shown 

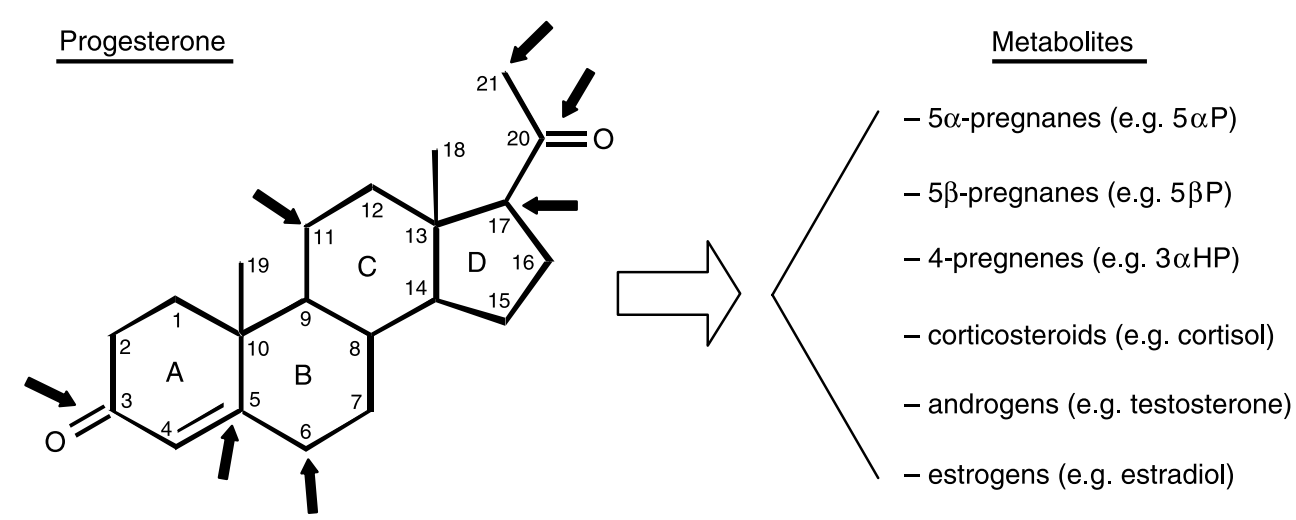

Figure 1 The structure of progesterone and the major classes of steroids resulting from its metabolism. $\mathrm{P}$, the 21 -carbon precursor of all the major steroid hormones produced in the gonads and adrenals, is also directly altered by enzymes within many, if not all, other tissues. The enzymes are specific for particular sites on the molecule (examples indicated by the arrows) and their actions lead directly to the $5 \alpha$-pregnane, $5 \beta$-pregnane, and 4-pregnene metabolites of $\mathrm{P}$ and indirectly to the corticosteroids, androgens, and estrogens. In this review, evidence is presented that in human breast tissue $5 \alpha$-pregnanes and 4-pregnenes are hormones whose actions may determine normalcy or progression to breast cancer.

the presence in these tissues of a number of enzymes capable of converting P to a variety of products.

Numerous studies provided evidence that many of the same P-metabolizing enzymes also exist in tissues that are not directly associated with reproduction. These include various regions of the central and peripheral nervous systems (brain, cortex, spinal cord, olfactory bulb, optic lobe, medulla oblongata, cortex corpus callosum, pineal, hypothalamus, pituitary, telencephalon, and neuronal and glial cells) from quail (Ukena et al. 2001, Matsunaga et al. 2004), chicken (Balthazart et al. 1988, Pignataro et al. 1998), rat (Hanukoglu et al. 1977, Marrone \& Karavolas 1981, 1982, Bertics et al. 1987, Korneyev et al. 1993, Martini et al. 1993, Stuerenburg et al. 1997, Wiebe et al. 1997, Pomata et al. 2000, Rhodes \& Frye 2001), mouse (Korneyev et al. 1993), monkey (Korneyev et al. 1993), and human (Melcangi et al.1993, 1994, Patte-Mensa et al. 2005). P is also metabolized by diverse tissues/cells such as fibroblasts (Perlman et al. 1960, Zhang et al. 1999), heart cells (Desgres et al. 1980), blood cells (Seamark et al. 1970), skin (Frost et al. 1969, Mauvais-Jarvis et al. 1969), salivary glands (Ferguson \& Bannon 1983, Laine \& Ojanotko-Harri 1990), saliva (Laine \& Ojanotko 1999), and amniotic fluid (Beling \& Cederqvist 1978). Invariably, the products of $\mathrm{P}$ metabolism in this diverse array of tissues consist of 21-carbon compounds.

Thus, many metabolism studies from a large number of tissues and various species had indicated that, in addition to the gonads and adrenals, perhaps most, if not all, tissues have some capacity to convert $P$ to other products. The studies had demonstrated the presence in tissues and cells of a number of enzymes capable of acting on various sites in the $\mathrm{P}$ molecule, leading to the formation of various classes of 21-carbon steroids, in addition to the known hormones, as illustrated in Fig. 1. These P-metabolizing enzymes included $5 \alpha-$ reductase, $5 \beta$-reductase, $3 \alpha$-hydroxysteroid oxidoreductase ( $3 \alpha-\mathrm{HSO}), 3 \beta-\mathrm{HSO}, 20 \alpha-\mathrm{HSO}, 20 \beta-\mathrm{HSO}$, $6 \alpha(\beta)-, 11 \beta-, 17-$, and 21-hydroxylase, and $\mathrm{C}_{17-20^{-}}$ lyase. In spite of this large number of enzymes capable of local transformation of $\mathrm{P}$, the 21-carbon $\mathrm{P}$ metabolites were for the most part considered to be waste products and the P-metabolizing enzymes as a means of controlling the local (in tissue) concentrations of $\mathrm{P}$.

In terms of neoplasia, the presence of P-metabolizing enzymes had been demonstrated in rat testicular interstitial cell tumors (Chatani et al. 1990), androblastoma (Sertoli-Leydig cell tumor) (Stegner \& Lisboa 1984), dimethylbenz(a)anthracene (DMBA)induced rat mammary tumors (Mori et al. 1978, Mori \& Tamaoki 1980, Eechaute et al. 1983), human endometrial carcinoma (Collins \& Jewkes 1974, Pollow et al. 1975), human breast tissues (Lloyd 1979, Miller 1990), modified breast cancer cell lines (T47Dco) (Fennessey et al. 1986, Horwitz et al. 1986), and virally transformed adrenocortical cells (Wiebe $e t$ al. 1987). Although selective differences in $\mathrm{P}$ metabolizing enzyme activities between normal and tumor tissues were noted in some of these studies, they were not linked to any potential effects of the metabolites themselves on cancer induction or promotion prior to our studies (Wiebe et al. 2000). 


\section{Progesterone metabolism in breast tissues and breast cell lines}

$\mathrm{P}$ was known to be involved in normal breast development as well as in the proliferative changes that occur during the menstrual cycle, pregnancy, and lactation (Going et al. 1988, Potten et al. 1988). However, its direct role in mammary cancer was not clear (McGuire \& Horwitz 1977, King 1993) and a number of studies provided conflicting results. Some reports indicated stimulation (Anderson et al. 1989), while others observed regression of, or no effect on, human tumors (Horwitz et al. 1985, Santen et al. 1990) resulting from treatment with $\mathrm{P}$ or synthetic progestins. Similarly, in other species such as rodents (Jabara 1967, Welsh 1982, Luo et al. 1997) and dogs (Segaloff 1975, Mol et al. 1996), progestins were shown to either stimulate or inhibit tumor growth. In vitro studies of the effects of progestins on human breast cancer cell lines likewise showed either stimulation or inhibition of cell proliferation and cell cycle progression (Braunsberg et al. 1987, Clark \& Sutherland 1990, Cappelletti et al. 1995, King 1993, Pike et al. 1993, Musgrove \& Sutherland 1994, Clarke et al. 1994, Groshong et al. 1997).

The conflicting results regarding the role of $\mathrm{P}$ in breast cancer, in addition to the lack of evidence that tumor progression could be substantially related to changes in in situ $\mathrm{P}$ levels, led us to speculate about the potential importance of further metabolism of steroids occurring locally within the tumor and its adjacent host tissue. This led us to hypothesize that $\mathrm{P}$ may be converted within breast tissue into several types of metabolites, some of which stimulate while others inhibit cell proliferation and tumorigenesis. By this hypothesis, $\mathrm{P}$ would serve as a precursor (or prohormone) and the metabolites as the active hormones in regulating breast cancer. The state or progression of mammary tumors could then depend on the ratio of cancer-promoting to cancer-inhibiting steroid compounds. If such $\mathrm{P}$ metabolites could be shown to exist, they might provide an alternate or additional endocrine explanation for the estrogen-sensitive and -insensitive breast carcinomas as well as for normalcy of breast tissues.

\section{Breast tissues and breast cell lines convert progesterone to $5 \alpha$-pregnanes and 4-pregnenes}

To test the hypothesis, studies were conducted to determine the capacity of tumor and surrounding normal (nontumorous) breast tissues to metabolize $\left[{ }^{14} \mathrm{C}\right] \mathrm{P}$. The paired tissue specimens came from premenopausal, menopausal and postmenopausal women with various subtypes and grades of infiltrating duct carcinomas and included tissues that were estrogen-receptor (ER) and progesterone-receptor (P) negative and/or positive (Wiebe et al. 2000). All the breast biopsies examined converted $\left[{ }^{14} \mathrm{C}\right] \mathrm{P}$ into at least ten different metabolites that could be grouped into two structurally different classes of steroids (illustrated in Fig. 2): those with a delta-4 double bond in ring A (the 4-pregnenes) and those that are $5 \alpha$-reduced (the $5 \alpha$ pregnanes). Reduction of $\mathrm{P}$ to $5 \alpha$-pregnanes is catalyzed by $5 \alpha$-reductase and the direct $5 \alpha$-reduced

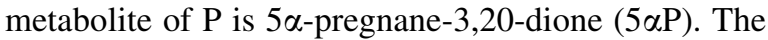
$5 \alpha$-reductase reaction is irreversible, but $5 \alpha \mathrm{P}$ can in turn be altered to 3- and 20-hydroxy pregnanes by the reversible actions of $3 \alpha-\mathrm{HSO}, 3 \beta-\mathrm{HSO}$, and $20 \alpha-\mathrm{HSO}$ (Fig. 2).

The two 4-pregnenes resulting from direct $\mathrm{P}$ conversion are 4-pregnen-3 $\alpha$-ol-20-one ( $3 \alpha \mathrm{HP})$ and

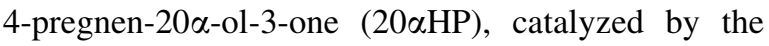
actions of $3 \alpha$-HSO and $20 \alpha$-HSO respectively (Fig. 2).

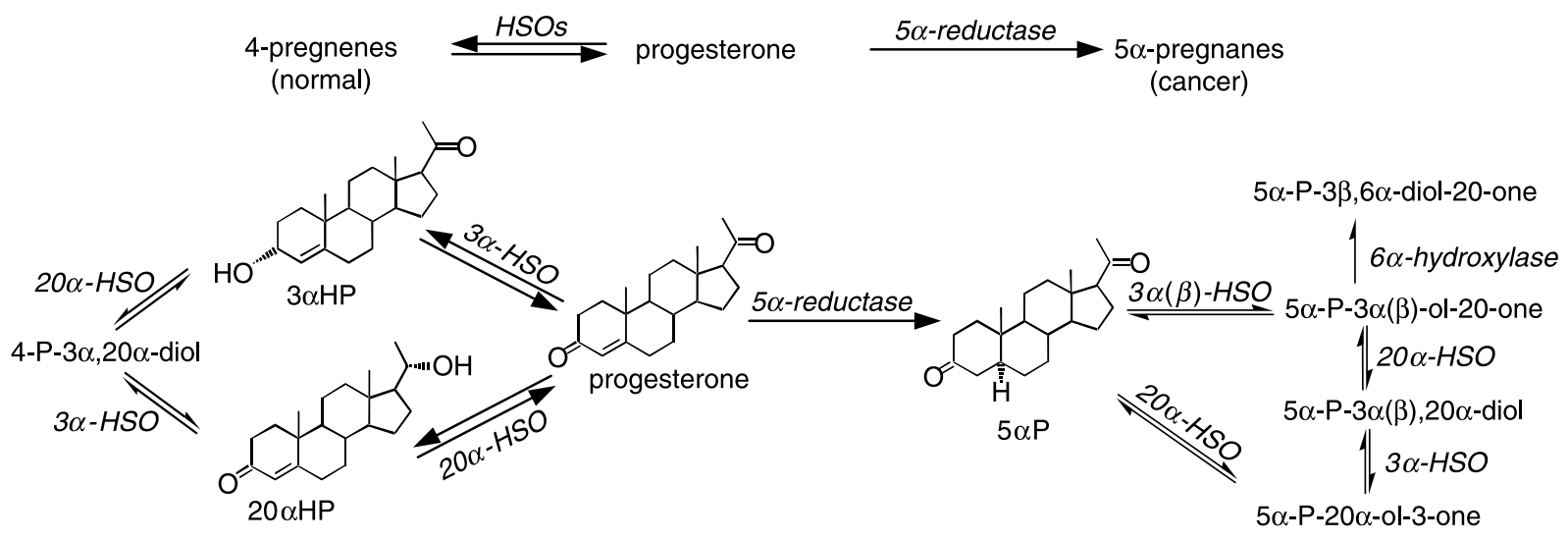

Figure 2 Progesterone conversion to 4-pregnene and $5 \alpha$-pregnane metabolites by human breast tissues and cell lines. Note that $5 \alpha$-reductase reaction is not reversible (see text for details; modified from Wiebe et al. 2005). 
The 4-pregnenes can be further reversibly converted to 4-pregnene- $3 \alpha(3 \beta), 20 \alpha$-diol. The same metabolic pathways were subsequently demonstrated in four different breast cell lines (Wiebe \& Lewis 2003) and had been previously identified in a number of tissues, including gonads, pituitary, and hypothalamus (Wiebe 1997). In addition, in the human breast cell lines, the final major product was $5 \alpha$-pregnane-3 $\beta, 6 \alpha$-diol-20one, indicating the presence of $6 \alpha$-hydroxylase, an enzyme that was also present in tissues at minor activity levels. Thus, the P-metabolizing enzyme activities identified in human breast tissues and cell lines were: $5 \alpha$-reductase, $3 \alpha$-HSO, $3 \beta$-HSO, $20 \alpha$ HSO, and $6 \alpha$-hydroxylase (Fig. 2).

\section{Changes in progesterone metabolite ratios and metabolizing enzyme activities}

Although both normal (nontumorous) and tumorous breast tissues converted $\mathrm{P}$ to the two classes of metabolites, there were significant quantitative differences. In normal breast tissue, conversion to 4-pregnenes greatly exceeded the conversion to $5 \alpha$-pregnanes, whereas in tumorous tissue, conversion to $5 \alpha$-pregnanes greatly exceeded that to 4-pregnenes (Fig. 3a). The differences in amounts of $5 \alpha$-pregnanes and 4-pregnenes were mainly due to changes in the amounts of $5 \alpha \mathrm{P}$ and $3 \alpha \mathrm{HP}$ (Fig. 3b) and the ratio of $5 \alpha \mathrm{P}: 3 \alpha \mathrm{HP}$ was nearly 30 -fold higher in tumorous than in normal breast tissues. The results indicated that P $5 \alpha$-reductase activity is significantly higher, whereas $\mathrm{P} 3 \alpha-\mathrm{HSO}$ and $20 \alpha-\mathrm{HSO}$ activities are significantly lower in tumor than in normal tissues (Wiebe et al. 2000). Earlier studies with cell-free homogenates of breast tissues (Lloyd 1979, Miller 1990) and chemically induced rat mammary tumors (Mori et al. 1978) had also shown higher $5 \alpha$-reductase and lower $20 \alpha$-HSO activities in tumors than in normal glands.

Confirmation of a shift in actual amounts of $\mathrm{P}$ metabolites in the breast microenvironment has been provided, in part, by measurements of $5 \alpha \mathrm{P}$ and $3 \alpha \mathrm{HP}$ levels in breast tissue and nipple aspirate fluids (J P Wiebe, E Sauter \& G Zhang unpublished results). The amounts of $5 \alpha \mathrm{P}$ and $3 \alpha \mathrm{HP}$ in a paired tissue sample, determined by gas chromatography-mass spectrometry, showed that levels (ng/mg protein) were 15.5 and 4.3 for $5 \alpha \mathrm{P}$ and 5.5 and 12.7 for $3 \alpha \mathrm{HP}$ respectively in the tumor and adjacent nontumor portion, confirming a higher $5 \alpha \mathrm{P}: 3 \alpha \mathrm{HP}$ ratio in the tumor portion of the breast. An indication of the molar concentrations of $\mathrm{P}$ and the metabolites, $5 \alpha \mathrm{P}$ and $3 \alpha \mathrm{HP}$, in breast microenvironment was obtained by RIA measurements of breast nipple aspirate fluids from four tumorous breasts (Table 1). Of note is that the concentrations in the aspirate fluid are high, being in the micromolar range. Although the values for $5 \alpha \mathrm{P}$ varied considerably (perhaps due to the lack of specificity of the $5 \alpha \mathrm{P}$ antibody), on average the levels of $5 \alpha \mathrm{P}$ were higher than the levels of $3 \alpha \mathrm{HP}$; the concentrations of $5 \alpha \mathrm{P}$ were $5.23 \pm 2.51 \mu \mathrm{M}$ and those of $3 \alpha \mathrm{HP}$ were $1.03 \pm 0.08 \mu \mathrm{M}$. The differences in levels suggest active metabolism of the (a)

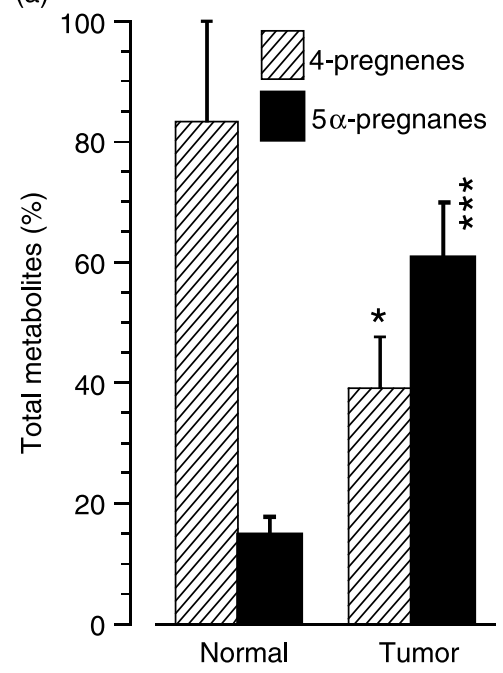

(b)

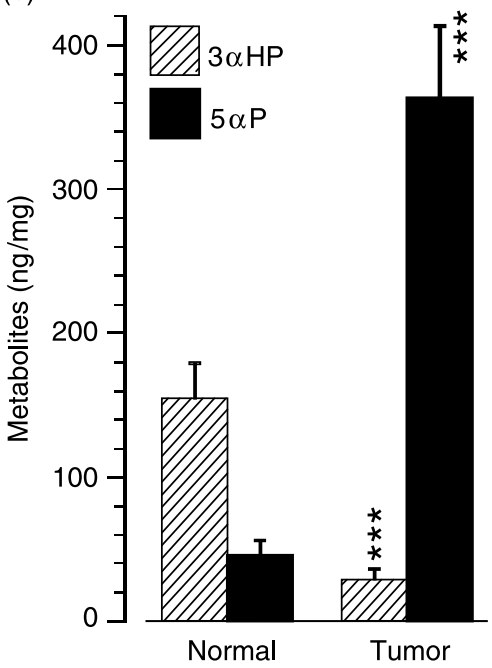

(c)

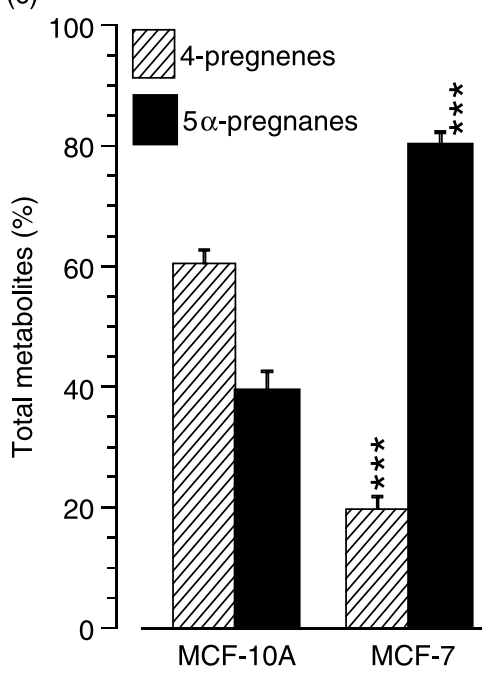

Figure 3 Differences in $\mathrm{P}$ metabolism between paired nontumorous (normal) and tumorous (tumor) human breast tissues ((a) and (b)) and between nontumorigenic (MCF-10A) and tumorigenic (MCF-7) human breast cell lines (c). In (a) and (c), the conversion to 4pregnenes and $5 \alpha$-pregnanes is presented as percentage of total P metabolism. In (b) the amounts of the specific metabolites, $3 \alpha \mathrm{HP}$ and $5 \alpha \mathrm{P}$, formed from $\mathrm{P}$ by tissues is given as nanogram/milligram protein. * ${ }^{*}$, significantly different from normal at $P<0.05$; ${ }^{\star * *}$, significantly different from normal ((a) and (b)) or from MCF-10A (c) at $P<0.001$. (Modified from Wiebe et al. 2000, Wiebe \& Lewis 2003.) 
Table 1 Levels of $5 \alpha \mathrm{P}, 3 \alpha \mathrm{HP}$, and progesterone in breast nipple aspirate fluid samples from tumorous breasts

\begin{tabular}{|c|c|c|c|c|c|c|}
\hline \multirow[b]{2}{*}{ Specimen $^{a}$} & \multicolumn{2}{|c|}{$5 \alpha \mathrm{P}$} & \multicolumn{2}{|c|}{$3 \alpha \mathrm{HP}$} & \multicolumn{2}{|c|}{ Progesterone } \\
\hline & $(\mathrm{ng} / \mu \mathrm{l})$ & $(\mu \mathrm{M})$ & $(\mathrm{ng} / \mu \mathrm{l})$ & $(\mu \mathrm{M})$ & $(\mathrm{ng} / \mu \mathrm{l})$ & $(\mu \mathrm{M})$ \\
\hline 1 & 1.10 & (3.48) & 0.38 & (1.2) & 3.10 & $(9.87)$ \\
\hline 2 & 1.22 & (3.86) & 0.36 & (1.14) & 1.72 & (5.48) \\
\hline 3 & 0.33 & (1.04) & 0.30 & $(0.95)$ & 5.56 & (17.7) \\
\hline 4 & 3.96 & (12.53) & 0.26 & $(0.82)$ & 1.70 & (5.41) \\
\hline Mean \pm S.E.M. & $1.65 \pm 0.79$ & $(5.23 \pm 2.51)$ & $0.33 \pm 0.03$ & $(1.03 \pm 0.08)$ & $3.02 \pm 0.91$ & $(9.62 \pm 2.89)$ \\
\hline
\end{tabular}

${ }^{\mathrm{a} B r e a s t}$ nipple aspirate fluid samples (provided by Dr E. Sauter, University of Missouri, Coumbia, MO, USA), were extracted and steroids separated chromatographically and measured by RIAs by methods similar to those described (Wiebe et al. 1991).

locally available $\mathrm{P}$ (also present at micromolar concentrations) and the ability of the cells to alter the microenvironment in terms of the $\mathrm{P}$ metabolites.

To determine if breast cell lines exhibit differences in direction of $\mathrm{P}$ metabolism related to tumorigenicity, estrogen response and/or ER/P status, four breast cell lines with varying characteristics were used (Wiebe \& Lewis 2003). Three of the cell lines (MCF-7, MDA-MB231, T47D) are known to be tumorigenic in immunodeficient mice (Anderson et al. 1984, Soto et al. 1986); among these, MCF-7 and T47D cells are ER/P-positive (Horwitz et al. 1975) and estrogen-dependent for tumorigenicity, whereas MDA-MB-231 cells are ER/Pnegative and develop tumors spontaneously without estrogen. The fourth cell line, MCF-10A, is ER/Pnegative and considered to be nontumorigenic (Soule et al. 1990). The results showed that production of $5 \alpha$-pregnanes was higher and that of 4-pregnenes was lower in tumorigenic (e.g. MCF-7) than in nontumorigenic (e.g. MCF-10A) cells (Fig. 3c), while differences in $\mathrm{ER} / \mathrm{P}$ status did not appear to play a role (Wiebe \& Lewis 2003). The 5 $\alpha$-pregnane-to-4-pregnene ratios were 7- to 20 -fold higher in the tumorigenic than in the nontumorigenic cell lines, providing essentially the same pattern of results as for the tissues.

Overall, the metabolism studies showed that the altered direction in $\mathrm{P}$ metabolism, and hence in metabolite ratios, was due to significantly elevated $5 \alpha$-reductase and depressed $3 \alpha$ - and $20 \alpha$-HSO activities in breast tumor tissues and tumorigenic cells. It appeared, therefore, that changes in P-metabolizing enzyme activities might be related to the shift toward mammary cell tumorigenicity and neoplasia. The changes in enzyme activity might reasonably be expected to be due to changes in expression of the enzyme genes.

\section{Changes in expression of progesterone- metabolizing enzymes}

The above metabolic studies and in vitro enzyme kinetics studies showed that the activity of $5 \alpha$-reductase is higher, whereas that of the $3 \alpha(20 \alpha)$-HSOs is lower in tumor tissue and tumorigenic breast cell lines than in normal breast tissue and cell lines. Several factors can account for changes in enzyme activity. In vivo, changes in enzyme activity can result from changes in levels of the enzyme due to changes in expression of the mRNA coding for the enzyme, or from changes in the milieu in which the enzyme operates (such as temperature and $\mathrm{pH}$, and concentrations of cofactors, substrates, products, competitors, ions, phospholipids, and other molecules). In in vitro experiments, the milieu is carefully controlled to be identical between incubations, and therefore, observed differences can be more easily ascribed to differences in enzyme amounts.

To determine if the differences in P-metabolizing enzyme activities between normal and carcinoma tissues/cells could be attributed to changes in enzyme mRNA expression, reverse transcriptase (RT)-PCR studies were carried out on breast tissues and cells lines. RT-PCR analyses on tissues from 38 patients showed significantly higher levels of expression of $5 \alpha-$ reductase type $1(S R D 5 A 1)$ and $5 \alpha$-reductase type 2 (SRD5A2) mRNA and significantly lower levels of expression of the $3 \alpha$-HSO type 2 (AKRIC 3 ), $3 \alpha-\mathrm{HSO}$ type $3(A K R 1 C 2)$ and $20 \alpha$-HSO (AKRIC1) mRNAs in the tumor tissues than in the normal tissues (Lewis et al. 2004) (Fig. 4a). These results were similar to those from enzyme mRNA expression studies on breast cell lines (Wiebe \& Lewis 2003), which showed higher $5 \alpha$-reductase and lower HSO gene expressions in tumorigenic than in nontumorigenic cell lines (Fig. 4b). Other reports also indicate lower HSO mRNA expression levels in tumor than in normal portions of breast ( $\mathrm{Ji}$ et al. 2004) and prostate tissues (Ji et al. 2003).

Overall, the enzyme activity and expression studies strongly suggest that $5 \alpha$-reductase stimulation and $3 \alpha$ - and $20 \alpha$-HSO suppression are associated with the transition from normalcy to cancer of the breast. It is tempting to speculate that factors in the mammary 
(a)

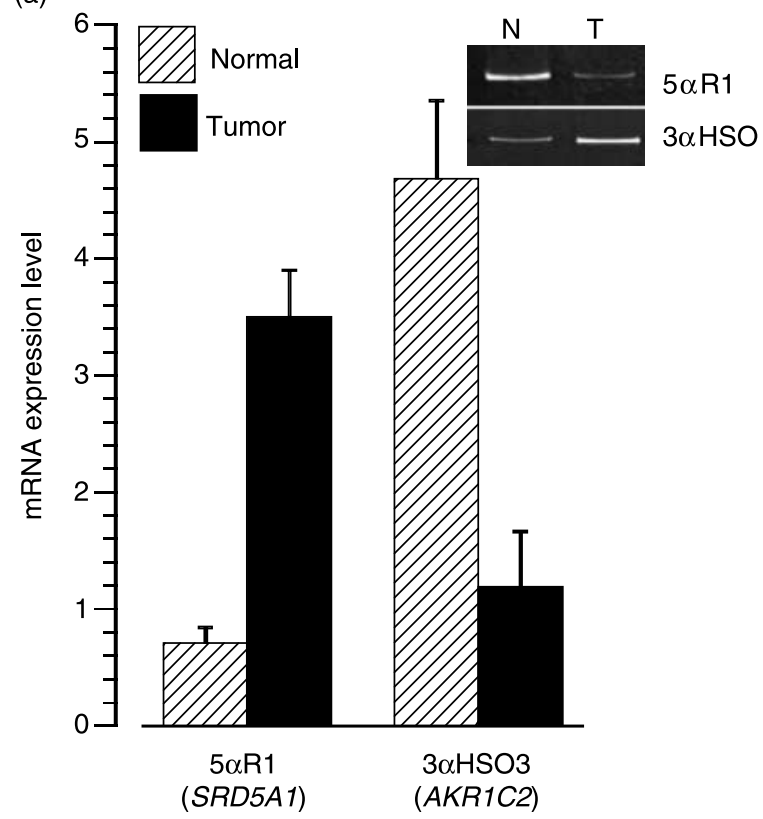

(b)

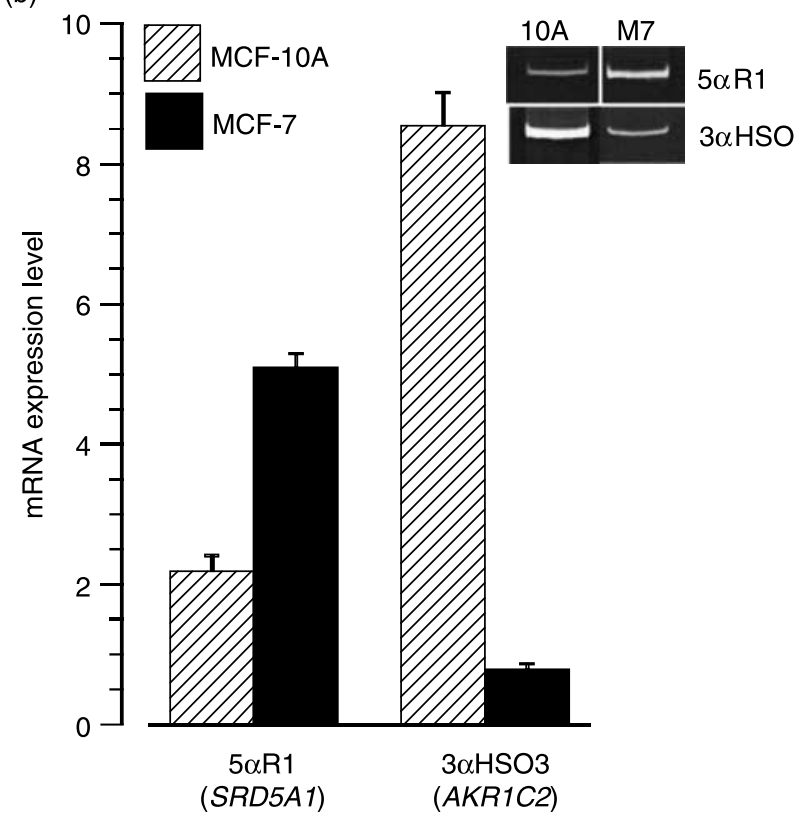

Figure 4 Examples of differences in progesterone-metabolizing enzyme expression levels (a) between paired normal and tumor breast tissues and (b) between nontumorigenic (MCF-10A) and tumorigenic (MCF-7) cell lines. For simplicity, only expression levels for $5 \alpha$-reductase type $1(5 \alpha-\mathrm{R} 1)$ and $3 \alpha$-HSO type $3(3 \alpha-\mathrm{HSO} 3)$ are shown; expression levels of the other enzyme genes $(5 \alpha-\mathrm{R} 2,3 \alpha-\mathrm{HSO} 2$, and $20 \alpha-\mathrm{HSO})$ showed similar differences. Insets show representative RT-PCR results (gels) for (a) one tumor (T) and adjacent normal (N) breast tissue sample, and (b) MCF-10A (10A) and MCF-7 (M7) cells. Differences between normal and tumor and between MCF-10A and MCF-7 are significant at $P<0.001$. (See Wiebe \& Lewis 2003, Lewis et al. 2004 for details.)

tissue milieu may be responsible for causing these changes in P-metabolizing enzyme gene expression and that these changes may be responsible for the transition. Steroid enzyme activities and gene expression have been shown in several tissues to be influenced by factors such as peptide hormones, cytokines, and steroids. For instance, prolactin acts as a paracrine/autocrine mutagenic agent in mammary cells (Clevenger \& Plank 1997, Das \&Vonderhaar 1997, Schroeder et al. 2002) and inhibits 20 $\alpha$-HSO expression in corpora lutea (Zhong \& Vonderharr 1997). In mammary gland cells, cytokines have been shown to regulate activity and expression of $3 \beta-\mathrm{HSO}$ (Gingras et al. 1999) and 17 $\beta$-HSO (Turgeon et al. 1998). The level of expression of $5 \alpha$-reductase is upregulated by estradiol and $\mathrm{P}$ in the uterus (Minjarez et al. 2001) and by $5 \alpha$-dihydrotestosterone (DHT) in the prostate (Andersson et al. 1989, Ji et al. 2003). And the expression of $20 \alpha$-HSO may be altered by $\mathrm{P}$ in corpora lutea (Sugino et al. 1997) and in endometrial cells (Nakajima et al. 2003). These examples suggest that the changes in P-metabolizing enzyme activity/ expression that lead to higher ratios of $5 \alpha$-pregnane:4pregnene may be induced by an altered milieu within the breast. Identification of the factors that may be responsible for changes in P-metabolizing enzyme expression awaits future investigations.

The studies cited above provided evidence of selective changes in levels of enzyme activities/expression and in P metabolites formed in breast carcinoma, but there was as yet no evidence that $\mathrm{P}$ metabolites exhibited regulatory functions related to cancer. Some of the same P metabolites had been identified as active regulatory molecules in other tissues and with respect to other processes. For example, $5 \alpha$-pregnanes such as $5 \alpha \mathrm{P}$ (Selye 1942), 5 $\alpha$-pregnan-3 $\alpha$-ol-20-one (Majewska et al. 1986, Kavaliers \& Wiebe 1987), and $3 \alpha \mathrm{HP}$ (Wiebe \& Kavaliers 1988) elicited marked anesthetic or analgesic effects via mechanisms involving calcium channels, the $\gamma$-aminobutyric acid(GABA)-benzodiazepine-chloride complex and endogenous opioid systems. 20 $\alpha \mathrm{HP}$ elevated serum follicle-stimulating hormone (FSH) and luteinizing hormone (LH) levels in rats (Gilles \& Karavolas 1981), whereas $3 \alpha \mathrm{HP}$ selectively suppressed basal and LH-releasing hormonestimulated FSH secretion from primary cultures of anterior pituitary cells (Wood \& Wiebe 1989) by nongenomic mechanisms at the level of the gonadotrope membrane, protein kinase $\mathrm{C}$ cell signaling pathway, and intracellular $\mathrm{Ca}^{2+}$ mobilization (Dhanvantari \& Wiebe 
1994, Wiebe et al. 1994b, Beck et al. 1997). The next step was to test the P metabolites for possible effects on mitogenic and metastatic parameters.

\section{Cancer-related actions of the progesterone metabolites}

Transformation of normal human cells into malignant cancers involves changes in, or deregulation of, a number of cell characteristics and processes (Hanahan \& Weinberg 2000). Cardinal among these are: (a) proliferation rates, (b) cell-to-cell and cell-to-substrate adhesion, (c) cytoskeletal and adhesion molecules, (d) receptors that transduce growth regulating signals, and (e) mitogenic growth signaling pathways. A summary of the effects of the P metabolites on these parameters follows.

\section{Effects of progesterone metabolites on cell proliferation, mitosis, and apoptosis}

Uncontrolled cell proliferation is one of the hallmarks of cancer, and factors which affect cell proliferation rates are known to affect cancer rates (Cohen \& Ellwein 1990, Pike et al. 1993, Hanahan \& Weinberg 2000). Initial studies conducted on MCF-7 cells showed significant, but opposite, effects on cell proliferation; $3 \alpha \mathrm{HP}$ inhibited whereas $5 \alpha \mathrm{P}$-stimulated proliferation dose-dependently between $10^{-9}$ and $10^{-6} \mathrm{M}$ (Fig. 5a). In this concentration range, estradiol resulted in weak stimulation at $10^{-8} \mathrm{M}$ and either no effects or slight inhibition at higher concentrations (Fig. 5a). Stimulation in cell numbers was also observed when cells were treated with other $5 \alpha-$

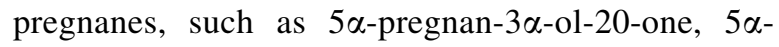
pregnan-20 $\alpha$-ol-3-one, and 5 $\alpha$-pregnane-3 $\alpha, 20 \alpha$-diol, whereas other 4-pregnenes such as $20 \alpha-\mathrm{HP}$ and 4-pregnene-3 $\alpha, 20 \alpha$-diol resulted in suppression of cell proliferation similar to that of $3 \alpha \mathrm{HP}$ (Wiebe et al. 2000). Stimulation of cell proliferation with $5 \alpha \mathrm{P}$ and inhibition with $3 \alpha \mathrm{HP}$ were also observed in all other breast cell lines examined, whether ER/Pnegative (MCF-10A, MDA-MB-231) or ER/P-positive (T47D, ZR-75-1) and whether requiring estrogen for tumorigenicity (MCF-7, T47D) or not (MDA-MB231), or whether they are nontumorigenic (MCF-10A) (Wiebe et al. 2000, Pawlak et al. 2005, G Zhang \& J P Wiebe, unpublished results).

Increases in cell numbers can result not only from increased rates of cell division, but also from decreases in rate of cell attrition via programmed cell death (apoptosis) (Thompson 1995). A balance of proliferation and apoptosis provides the homeostasis in normal tissues and alteration in this balance is postulated to set off a series of changes ultimately leading to malignancy. Studies on cell lines (Zhang et al. 2005, G Zhang \& J P Wiebe, unpublished results) using several methods of evaluating apoptosis and proliferation/mitosis showed that $3 \alpha \mathrm{HP}$ resulted in significant increases in apoptosis and decreases in mitosis, leading to significant decreases in total cell numbers. In
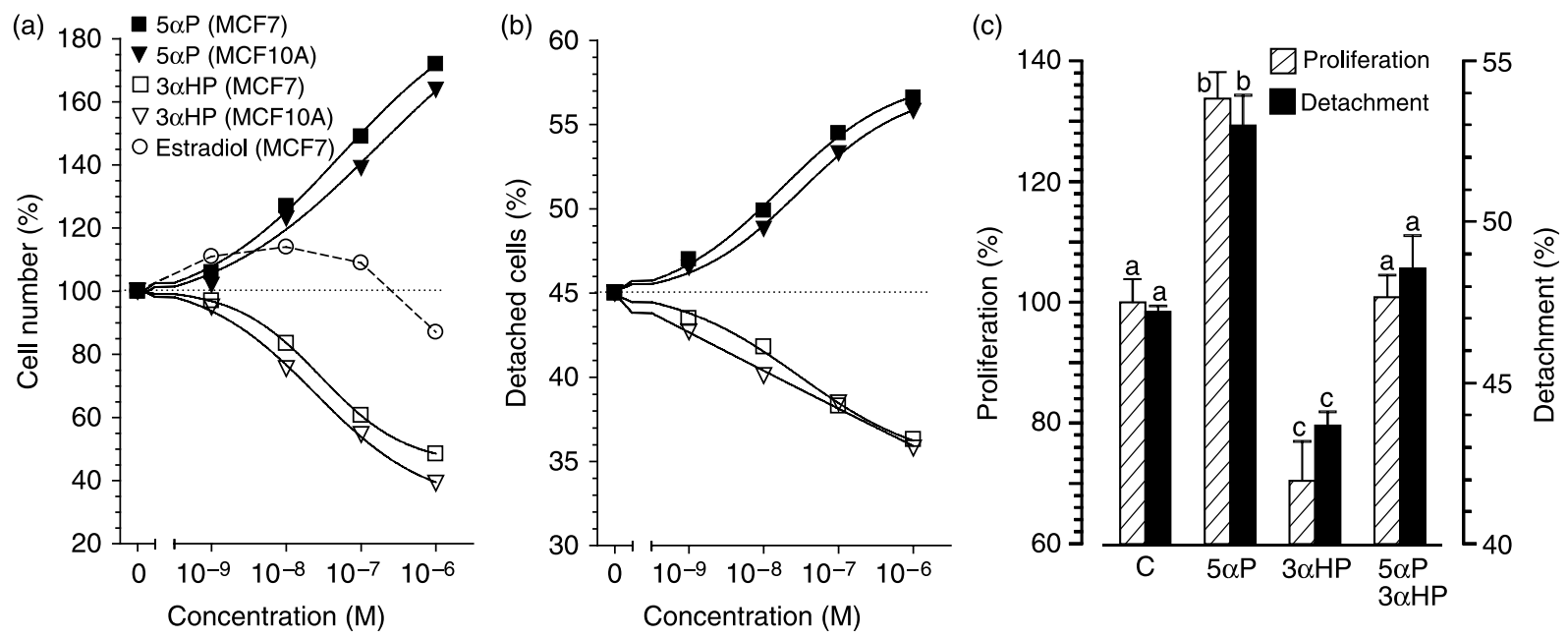

Figure 5 Effects of $5 \alpha \mathrm{P}$ and $3 \alpha \mathrm{HP}$ exposure $(72 \mathrm{~h}$ ) on proliferation (cell number) and adhesion (detachment) of MCF-7 and MCF-10A human breast cell lines. Values are presented as percent in relation to controls $(0, \mathrm{C})$. In (a) and (b) cells were exposed to 0 or $10^{-9}-10^{-6} \mathrm{M} 5 \alpha \mathrm{P}$ or $3 \alpha \mathrm{HP}$ and results show highly significant dose-dependent effects. In (a) MCF-7 cells were also exposed to estradiol for comparison purposes. The effect of combining $5 \alpha \mathrm{P}$ and $3 \alpha \mathrm{HP}$ (each at $10^{-7} \mathrm{M}$ ) on proliferation and detachment of MCF-7 cells are shown in (c); different letters $(a, b$, and c) on bars denote significant differences $(P<0.05)$ within proliferation or detachment results. (Modified from Wiebe et al. 2000, Wiebe \& Muzia 2001, Pawlak et al. 2005.) 
contrast, treatment with $5 \alpha \mathrm{P}$ resulted in decreases in apoptosis and increases in mitosis. Thus, with respect to overall cell proliferation effects, the results indicated that the actions of $3 \alpha \mathrm{HP}$ and $5 \alpha \mathrm{P}$ are diametrically opposed and involve both cell division and cell death. The results correlated with the metabolism studies in that the levels of the proliferation-inducing hormone $(5 \alpha \mathrm{P})$ were higher and those of the proliferationsuppressing hormone ( $3 \alpha \mathrm{HP}$ ) were lower in tumorous tissue and the reverse was true for normal tissue.

\section{Effects of progesterone metabolites on cell adhesion}

Cellular adhesion is a critical aspect of cancer biology. In culture conditions, normal cells of mesenchymal or epithelial origin generally depend on anchoring to a solid substratum for cell division. This dependence on support by solid substrates for cell proliferation is lessened as cells become neoplastic and metastatic (Raz 1988). Some time during the development of most types of human cancer, pioneer cells are spawned that are capable of moving out of the primary tumor masses and of traveling to distant sites where they may succeed in founding new colonies. It is these distant settlements of tumor cells - metastases - that are the cause of about $90 \%$ of human cancer deaths (Sporn 1996). The capability of escaping the primary tumor mass and colonizing new terrain involves a number of cellular changes, not the least of which are cell-cell and cell-substrate adhesion characteristics. To allow the initial escape, adhesion must be decreased and attachment severed.

To determine whether $\mathrm{P}$ metabolites might play a role in the acquisition of metastatic potential, their effects on cell adhesion were examined (Wiebe et al. 2000, Wiebe \& Muzia 2001) by quantitative cellsubstrate attachment and detachment assays that had been developed earlier (Dinsdale et al. 1992) for baby hamster kidney cells. The first tests were on MCF-7 cells and the results showed that $5 \alpha \mathrm{P}$ caused significant dose-dependent decreases in attachment to, and increases in detachment from, the substratum (Fig. 5b). The opposite effect was observed with $3 \alpha \mathrm{HP}$, which promoted cell attachment and decreased cell detachment (Fig. 5b). Similar effects have also been demonstrated recently in MCF-10A, T47D, and MDA-MB-231 cells (Wiebe et al. 2004, Pawlak et al. 2005). The opposing actions of $5 \alpha \mathrm{P}$ and $3 \alpha \mathrm{HP}$ on both cell anchorage and proliferation strengthen the hypothesis that the direction of $\mathrm{P}$ metabolism in vivo toward higher 5 $\alpha$-pregnane and lower 4-pregnene concentrations could promote breast neoplasia and lead to malignancy.

\section{Proof of principle}

Confirmation of the hypothesis that the move from normalcy to neoplasia in breast cells is influenced by the in situ increase in the 5 $\alpha$-pregnane:4-pregnene ratio requires studies in which $5 \alpha$-reductase activity is blocked, as well as paradigms where various concentrations of a $5 \alpha$-pregnane and a 4-pregnene are used in combination and in various temporal sequences. We have used the 4-azasteroid dutasteride, a known inhibitor of $5 \alpha$-reductase types 1 and 2 (Bramson et al. 1997) that has been employed in trials to inhibit the $5 \alpha$-reduction of testosterone to DHT in men with benign prostate hyperplasia (Brown \& Nuttal 2003, Clark et al. 2004) and prostate cancer (Andriole et al. 2004, Iczkowski et al. 2005). First, we demonstrated that in MCF-7 cells dutasteride at $10^{-6} \mathrm{M}$ inhibited $\mathrm{P}$ conversion to $5 \alpha$-pregnanes by $>95 \%$ and at the same time increased 4-pregnene production. Next, it was demonstrated that treatment of cells with $\mathrm{P}$ alone, without medium change for $72 \mathrm{~h}$, resulted in significant conversion to $5 \alpha-$ pregnanes and concomitant increases in cell proliferation and detachment. These increases in proliferation and detachment were blocked in cells incubated with $\mathrm{P}$ plus dutasteride. In turn, the suppression by dutasteride was overridden by the addition of $5 \alpha \mathrm{P}$. The results are seen as providing proof of the principle that the effects on proliferation and adhesion were not due to $\mathrm{P}$, but due to the $5 \alpha$-reduced metabolites (Wiebe et al. 2006).

To confirm the hypothesis that the ratio of $5 \alpha$-pregnanes:4-pregnenes is a determinant of the degree of cell proliferation and adhesion, detailed studies will need to be carried out using various concentrations of $3 \alpha \mathrm{HP}$ and $5 \alpha \mathrm{P}$ in combination and in various temporal sequences. Similar studies could also determine if the progression toward neoplasia can be impeded or even reversed by high $3 \alpha \mathrm{HP}: 5 \alpha \mathrm{P}$ ratios, i.e. ratios of $\mathrm{P}$ metabolites that favor the 4-pregnenes. Data from studies in which cells were treated simultaneously with both $3 \alpha \mathrm{HP}$ and $5 \alpha \mathrm{P}$ show that the independent effects of the individual hormones on proliferation and adhesion are cancelled out when present in equal concentrations (Fig. 5c) (Pawlak et al. 2005) and support the view that the overall effects may depend on the relative concentration of each in the milieu. 


\section{Effects of progesterone metabolites on cytoskeletal and adhesion complexes}

The transformations in morphology, replication, and adhesion during the transition from normal to cancerous cell have been shown to be accompanied by rearrangements of cytoskeletal and adhesion structures. The cytoskeletal organization differs between normal and cancerous cells (Ben-Ze'ev 1985, Holme 1990, Holth et al. 1998) and between high- and low-metastatic cells (Suzuki et al. 1998). For example, the level of organization of the actin cytoskeleton observed in normal cells (Bershadsky et al. 1995, Helige et al. 1997) is characterized by higher levels of polymerized actin, whereas transformation to the metastatic condition may be accompanied by disruption and/or visible disappearance of actin filaments (Suzuki et al. 1998). Similarly, vinculin, a protein that is associated with cell-to-cell and cell-tosubstrate adhesion sites (Wilkins \& Lin 1982, Luna \& Hitt 1992, Humphries \& Newham 1998), may show alterations. In normal cells, vinculin may be readily detected, while in highly malignant cell lines its organization may be significantly altered (Schliwa et al. 1984) or it may not be detected at all (Sadano et al. 1992), suggesting that depolymerization or suppression of vinculin expression may be closely related to progression of malignancy.

To determine the cellular sites of action of the proliferation- and detachment-promoting P metabolite, $5 \alpha \mathrm{P}$, its effects on MCF-7 cell morphology, F-actin expression, polymerization, and filament distribution, as well as vinculin expression and vinculin-containing adhesion plaque numbers, were examined by immunohistochemistry, morphometry, and western blotting (Wiebe \& Muzia 2001). Figure 6a shows typical distribution of polymerized actin filaments and terminal vinculin molecules in a normal cell. Treatment of cells with $5 \alpha \mathrm{P}$ resulted in dose-dependent decreases in vinculin-containing adhesion plaques and vinculin expression (Fig. 6b), as well as in polymerized actin stress fibers (Fig. 6c). Similar results were observed with MCF-10A, MDA-MB-231, and T47D breast cell lines (Wiebe et al. 2004), again confirming that the $\mathrm{P}$ metabolites appear to be able to target a variety of human breast cells. The results suggest that the observed decreases in adhesion and increases in cell proliferation following $5 \alpha \mathrm{P}$-treatment may be related to depolymerization of actin and decreased expression of vinculin.

\section{Receptors for progesterone metabolites in human breast cells}

\section{Localization and characterization of progesterone metabolite receptors}

The actions of hormonal steroids are considered to generally require complexing with specific-binding sites (receptors) on target cells. Therefore, an important step in elucidating the mechanisms of action of a regulatory hormone is the identification of such receptors. To identify potential binding sites for $\mathrm{P}$ metabolites in mammary cells, competition radioreceptor assays were
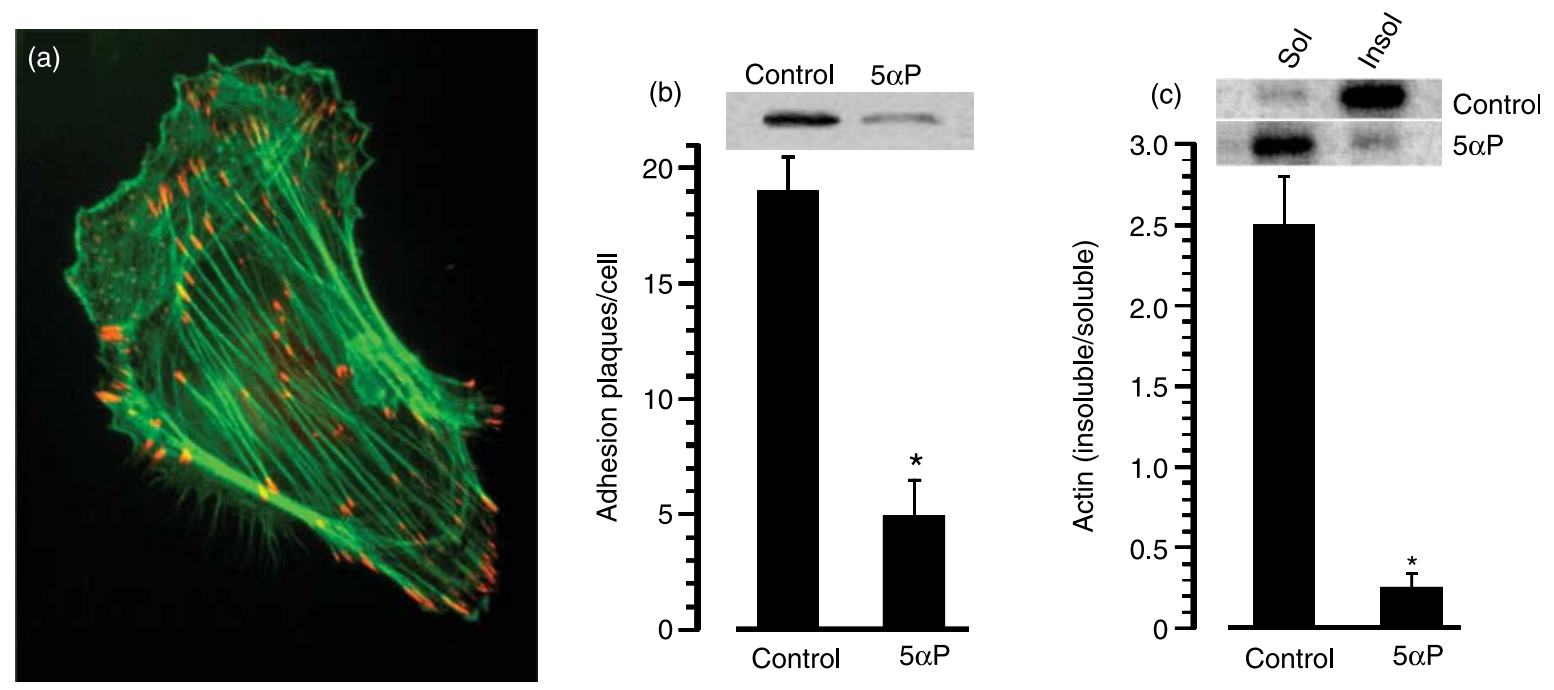

Figure 6 Examples of effects of $5 \alpha \mathrm{P}$ on cytoskeletal and adhesion complex molecules in MCF-7 cells. (a) The arrangement of vinculin-containing adhesion plaques (red) and polymerized F-actin fibers (green) is shown in a control cell. The effects of $5 \alpha \mathrm{P}$ $\left(10^{-6} \mathrm{M}\right)$ treatment result in marked reduction in vinculin expression (inset) and in number of vinculin-containing adhesion plaques (b), and depolymerization (insoluble to soluble change) of F-actin (c). (From Wiebe \& Muzia, 2001 and unpublished results). 
conducted on nuclear, cytosolic, and membrane fractions of MCF-7 and MCF-10A breast cell lines using $\left[{ }^{3} \mathrm{H}\right]$-labeled $5 \alpha \mathrm{P}$ and $3 \alpha \mathrm{HP}$ (Weiler \& Wiebe 2000, Pawlak et al. 2005). The studies showed that binding of $5 \alpha \mathrm{P}$ or $3 \alpha \mathrm{HP}$ occurs in the plasma membrane fractions, but not in the nuclear or cytosolic compartments (Fig. 7a). Saturation and Scatchard analyses indicated separate high-specificity, high-affinity, low- capacity receptors for $5 \alpha \mathrm{P}$ and $3 \alpha \mathrm{HP}$ that are distinct from each other and from the well-studied nuclear/cytosolic P, estrogen, and androgen and corticosteroid receptors; binding of $\left[{ }^{3} \mathrm{H}\right] 5 \alpha \mathrm{P}$ or $\left[{ }^{3} \mathrm{H}\right] 3 \alpha \mathrm{HP}$ was not displaced by 200 to 500-fold concentrations of P, estradiol, androgens, corticosteroids, and other $\mathrm{P}$ metabolites. In turn, binding of $\left[{ }^{3} \mathrm{H}\right] \mathrm{P}$ or $\left[{ }^{3} \mathrm{H}\right]$ estradiol to cytosolic or nuclear fractions was not displaced by excess $5 \alpha \mathrm{P}$ or $3 \alpha \mathrm{HP}$. The binding studies showed that the criteria of high affinity, specificity, saturability, and association and dissociation kinetics required of receptor designation (Laduron 1984, Limbird 1996) were met. The studies thus provided the first demonstration of the existence of specific $\mathrm{P}$ metabolite receptors. Identifying the presence of distinct and separate receptors for $3 \alpha \mathrm{HP}$ ( $3 \alpha \mathrm{HPR}$ ) and $5 \alpha \mathrm{P}$ ( $5 \alpha \mathrm{PR})$ in human breast cells is important in light of the findings that the two $\mathrm{P}$ metabolites exert opposing actions with respect to cell proliferation and adhesion.

\section{Regulation of progesterone metabolite receptor levels}

Since the action mechanisms of hormonal steroids are generally initiated by the binding to specific receptors, the level of cellular response to steroids is limited not only by the local concentration of the hormone, but also by the receptor number (Vanderbilt et al. 1987, Webb et al. 1992). Due to the potential importance of $5 \alpha \mathrm{P}$ in promoting breast cancer via the binding to its membrane-based receptors, the role of mitogenic (estradiol, $5 \alpha \mathrm{P})$ and anti-mitogenic ( $3 \alpha \mathrm{HP}, 20 \alpha \mathrm{HP}$ ) endogenous steroids on $5 \alpha \mathrm{PR}$ levels in a tumorigenic (MCF-7) and a nontumorigenic (MCF-10A) breast cell line were explored (Pawlak et al. 2005). Exposure of MCF-7 cells for $24 \mathrm{~h}$ to estradiol or $5 \alpha \mathrm{P}$ resulted in significant dose-dependent increases in $5 \alpha \mathrm{PR}$ levels (Fig. 7b), whereas $3 \alpha \mathrm{HP}$ or $20 \alpha \mathrm{HP}$ resulted in significant dose-dependent decreases in $5 \alpha \mathrm{PR}$ levels (Fig. 7c). Treatment with two mitogenic (estradiol or $5 \alpha \mathrm{P})$ or two anti-mitogenic ( $3 \alpha \mathrm{HP}$ or $20 \alpha \mathrm{HP})$ hormones resulted in additive effects on $5 \alpha \mathrm{PR}$ numbers (Fig. 7b and c), whereas treatment with one mitogenic and one anti-mitogenic hormone abolished the mitogen-induced increases (Fig. 7d). In addition, preliminary experiments in which MCF-7 cells were exposed to $1.0 \mathrm{nM}$ estradiol for $24 \mathrm{~h}$ showed a $60 \%$ decrease in $3 \alpha$ HPR numbers (Weiler \& Wiebe 2000).

The nontumorigenic breast cell line, MCF-10A, was also shown to posses specific, high-affinity plasma membrane receptors for $5 \alpha \mathrm{P}$ that are up-regulated by estradiol and $5 \alpha \mathrm{P}$ and down-regulated by $3 \alpha \mathrm{HP}$ (Pawlak et al. 2005). Estradiol binding was demonstrated in MCF-10A cell membrane fractions and may explain the estradiol action in these cells, which reportedly lack intracellular ER. In both MCF-7 and MCF-10A cells, the increases in $5 \alpha \mathrm{PR}$ due to estradiol or $5 \alpha \mathrm{P}$ and decreases due to $3 \alpha \mathrm{HP}$ or $20 \alpha \mathrm{HP}$ correlated with respective increases and decreases in cell proliferation as well as detachment (Pawlak et al. 2005), indicating the functional relevance of
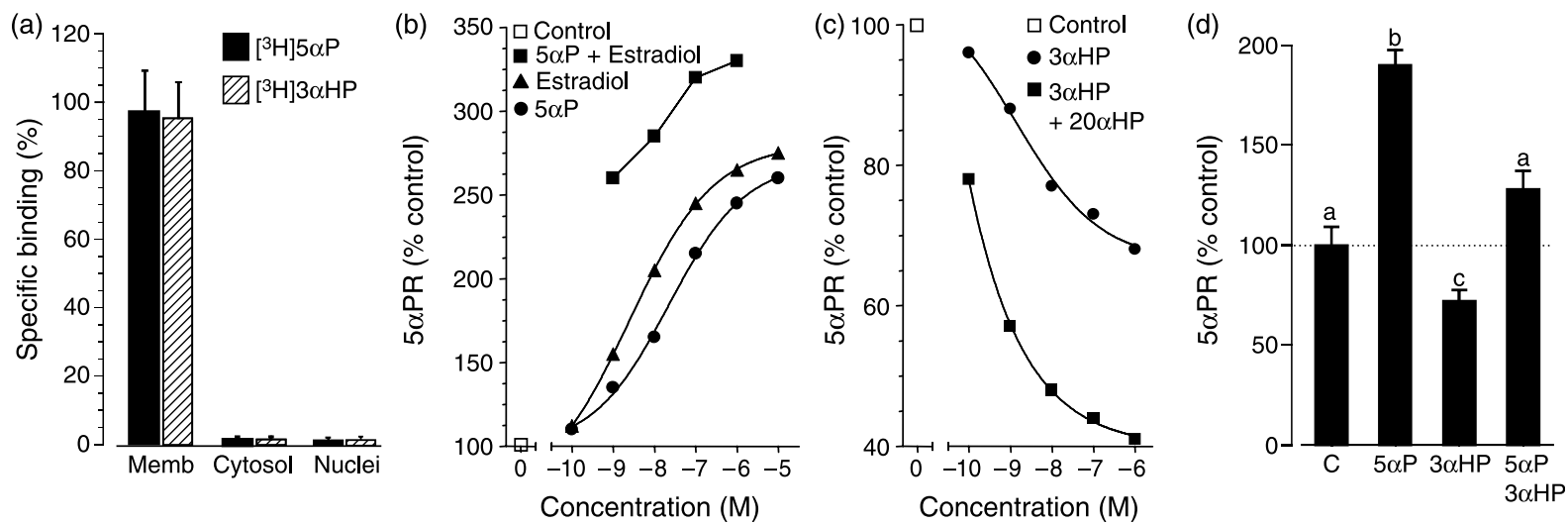

Figure 7 Binding sites (receptors) for progesterone metabolites in MCF-7 and MCF-10A human breast cell lines. Specific, saturablebinding sites (receptors) for $5 \alpha \mathrm{P}$ and $3 \alpha \mathrm{HP}$ are located only in the membrane fraction (a). $5 \alpha \mathrm{P}$ receptors (5 $\alpha \mathrm{PR}$ ) are significantly, dose-dependently and additively up-regulated by estradiol and $5 \alpha \mathrm{P}$ (b) and down-regulated by $3 \alpha \mathrm{HP}$ and $20 \alpha \mathrm{HP}$ (c). The increases and decreases in $5 \alpha \mathrm{PR}$ numbers due to $5 \alpha \mathrm{P}$ and $3 \alpha \mathrm{HP}$ respectively are abolished when cells are treated simultaneously with both hormones (d). (From Weiler \& Wiebe, 2000 and Pawlak et al. 2005.) 
alterations in $5 \alpha \mathrm{PR}$ concentrations. Together, the receptor results suggest that the putative tumorigenic actions of $5 \alpha \mathrm{P}$ may be significantly augmented by the estradiol-induced increases in $5 \alpha \mathrm{P}$ binding and decreases in $3 \alpha \mathrm{HP}$ binding.

\section{Role of progesterone metabolites in regulating ER levels}

Estradiol can influence mitogenicity of ER-positive mammary cells and therefore the regulation of ER levels may be important for the progression of estrogen-dependent mammary neoplasias. Estradiol and $\mathrm{P}$ are known to play a role in modulating ER concentrations (Shyamala et al. 2002). To determine if $\mathrm{P}$ metabolites affect ER levels, MCF-7 cells were exposed for $24 \mathrm{~h}$ to $5 \alpha \mathrm{P}, 3 \alpha \mathrm{HP}, 20 \alpha \mathrm{HP}$, and estradiol, or combinations of these steroids, and ER concentrations were determined in cytosolic and nuclear fractions by specific-binding of $\left[{ }^{3} \mathrm{H}\right]$ estradiol (Pawlak $\&$ Wiebe 2005). Estradiol and $5 \alpha \mathrm{P}$ resulted in significant dose-dependent increases, whereas $3 \alpha \mathrm{HP}$ and $20 \alpha \mathrm{HP}$ each resulted in dose-dependent decreases in total ER as well as inhibition of estradiol- or $5 \alpha \mathrm{P}-$ induced ER levels. In combination, estradiol $+5 \alpha \mathrm{P}$ or $3 \alpha \mathrm{HP}+20 \alpha \mathrm{HP}$ resulted in additive increases or decreases respectively in ER numbers.

The results are the first to show that the pro- and anti-cancer $\mathrm{P}$ metabolites have also marked selective (up or down) regulatory effects on ER levels in ERpositive MCF-7 breast cancer cells. The suggested implications for breast cancer are that the stimulatory and inhibitory effects of $5 \alpha \mathrm{P}$ and $3 \alpha \mathrm{HP}$ respectively on cell replication and cell detachment might be significantly modified by exposure to estradiol, 4-pregnenes, and $5 \alpha$-pregnanes and, in turn, that the $\mathrm{P}$ metabolites may significantly affect ER response in estrogentargeted cells.

\section{Effect of the progesterone metabolite, $5 \alpha \mathrm{P}$, on cell signaling pathways}

The location of the receptors for $5 \alpha \mathrm{P}$ and $3 \alpha \mathrm{HP}$ on the cell membrane suggests involvement of nongenomic mechanisms of action via cell signaling pathways. Modes of action via plasma membrane-based binding sites and cell signaling pathways have been suggested for estradiol (Watson et al. 1999, Keshamouni et al. 2002, Purves-Tyson \& Keast 2004, Simoncini et al. 2004), corticosteroids (Wehling 1997, Croxtall et al. 2000), 3 $\alpha$ HP (Dhanvantari \& Wiebe 1994, Beck et al. 1997, Wiebe 1997), and neurosteroids such as the $P$ metabolite, $5 \alpha$-pregnan-3 $\alpha$-ol-20-one (allopregnanolone)
(Majewska et al. 1986). Signaling pathways that control cell proliferation and adhesion involve the mitogen-activated protein kinase (MAPK) pathway and, in turn, deregulation of this Ras-Raf-MEK-MAPK cascade plays a central role in human cancer (Chang \& Karin 2001, Pearson et al. 2001, Santen et al. 2002). Studies on serum-starved MCF-7 cells showed that treatment with $5 \alpha \mathrm{P}$ for as briefly as $5 \mathrm{~min}$ resulted in significant, dose-dependent increases in activated (phosphorylated) MAPK (Erk1/2) (Wiebe et al. 2005, Cialucu \& J P Wiebe, unpublished results). Treatment with the MEK inhibitor, PD98059, resulted in significant suppression of the $5 \alpha \mathrm{P}$-induced MAPK activation. Similarly, in concomitant cell proliferation $\left(\left[{ }^{3} \mathrm{H}\right]\right.$ thymidine uptake) and detachment assays, $5 \alpha \mathrm{P}$ resulted in significant increases in cell proliferation and detachment, whereas PD98059 significantly suppressed the $5 \alpha \mathrm{P}$-induced increases. The data suggest that the action of $5 \alpha \mathrm{P}$ on breast cancer cells involves modulation of the MAPK signaling pathway. Whether other cell signaling pathways are involved or $5 \alpha \mathrm{P}$ and $3 \alpha \mathrm{HP}$ act via different pathways in promoting or inhibiting neoplasia in breast cells remain to be explored.

\section{Implications of changes in progesterone $5 \alpha$-reductase activity for androgen action in breast cancer}

Although the majority of primary human breast cancers express androgen receptors, no direct association with any androgen and breast cancer growth and progression has been convincingly established (Bradlow \& Sepkovic 2004). How might the up-regulation in $5 \alpha$-reductase in neoplastic breast tissue influence androgen metabolism in the breast and in turn affect the role of transformed androgens in breast cancer?

Suzuki et al. (2001) have suggested that increased conversion of testosterone to DHT resulting from increased $5 \alpha$-reductase activity should inhibit cancer cell proliferation in human breast carcinoma. However, studies with ZR-75-1 (Poulin et al. 1988, Birrell et al. 1995, Kandouz et al. 1999), T47-D (Birrell et al. 1995, Ortmann et al. 2002), MDA-MB-231 (Di Monaco et al. 1995, Ortmann et al. 2002), MFM-223 (Hackenberg et al. 1991), and CAMA-1 cells (Lapointe \& Labrie 2001) and with DMBA-induced rat mammary tumors (Boccuzzi et al. 1995) have shown that both testosterone and DHT inhibit cell growth more or less to the same extent. This is in marked contrast to the actions of $\mathrm{P}$ metabolites, where the $5 \alpha$-pregnanes stimulate and the 4-pregnenes inhibit cell proliferation. Also, 5 $\alpha$-reductase type 2 (SRD5A2), which catalyzes 
reduction of testosterone to DHT in androgendependent tissues such as the prostate, is present in very low levels in breast tissue (Ji et al. 2004, Lewis et al. 2004) and human breast cancer cell lines (Wiebe $\&$ Lewis 2003). In breast tissue, 5 $\alpha$-reductase type 1 (SRD5A1) is predominant and it may be that $\mathrm{P}$ is a better substrate than testosterone for this isoenzyme. Overall, current evidence does not appear to support the notion that increased $5 \alpha$-reductase activity/ expression might significantly alter androgen influences on breast tumor growth.

\section{Implications of progesterone-metabolizing enzymes for synthetic progestin-based contraceptives and hormone-replacement therapy drugs}

The synthetic progestins used for contraception and hormone replacement therapy (HRT) do not behave like $\mathrm{P}$ in terms of their metabolism and probably not with respect to their actions at the level of the breast tissue microenvironment. As different formulations may exhibit marked differences in chemical structure, metabolism, and pharmacodynamic actions, it is not possible to generalize about them. The effects of the drugs at the level of the breast tissue will be governed by the molecular form and bioavailability, but unfortunately these are areas that remain unexplored. At the outset, the level of metabolism may vary greatly, depending on whether the route of administration is oral, transdermal, subcutaneous, or intravaginally (Fotherby 1996). When taken orally, many drugs are readily metabolized in the gastrointestinal tract and/or liver and the degree and site of metabolism varies substantially between different compounds. Some contraceptive and HRT drugs (for example, desogestrel, norgestimate, mestranol, norethisterone acetate, and ethinylestradiol-3-methyl ether) are in fact prodrugs and are converted into their active metabolites when taken orally (Fotherby 1996, Henzl 2001). On the other hand, compounds like Nestorone must be administered parenterally due to their rapid hepatic metabolism and apparent inactivation (Sitruk-Ware 2004). The different formulations also exhibit great variation in level of binding to serum proteins (Kuhl 1996, Hammond et al. 2003), potential action via estrogen, androgen, $\mathrm{P}$, and corticosteroid receptor binding and consequent androgenic, estrogenic, and progestational potency, and actions on enzymes (Kuhl 1996). To ascertain the possible role of the contraceptive and HRT drugs in breast cancer regulation via the $\mathrm{P}$ metabolites, it will be necessary to measure their levels and composition in the breast microenvironment to determine their effects on $\mathrm{P}$ metabolism in breast tissue and/or cell lines and to establish whether the Pmetabolizing enzymes can further alter the drugs to pro- or anti-cancer moieties.

\section{Summary, significance, and future prospects}

Mammary gland cells show cyclicity and respond to steroid hormones. Normal breast tissue goes through cycles of imbalance between proliferation and apoptosis during menstrual periodicity, pregnancy, and lactation, but regularly corrects these temporary imbalances. In cancer, changes have occurred such that overall increases in cell numbers continue and result in the development of tumors. The normal changes are believed to be due to the changes in concentration of the ovarian hormones, estradiol and P. Since estrogens have been shown to increase proliferation in some cells, and because about one-third of breast cancer patients show some responses to antiestrogen therapies, estrogens have been considered the primary hormonal cause of breast cancer. In time, however, estrogen-sensitive neoplasms become unresponsive and the patients experience relapse. Overall, this means the existence of an overwhelming majority of breast cancers for which the current estrogens based explanations and therapies are inadequate. Since P appears to be involved in the normal cyclical changes, it too has been implicated in breast neoplasia, but its role has been unclear and no specific categories of breast cancers have been shown to respond unambiguously to $\mathrm{P}$ or to anti-progestins. The end result is that for the majority of breast cancers, current estradiol/Pbased explanations are inadequate and therapies ultimately ineffective. Moreover, estradiol and $\mathrm{P}$ do not provide hormone-based explanations for those breast tissues that do not become cancerous.

The $\mathrm{P}$ metabolites, produced within breast tissues, are put forward as potential candidates that could up- or down-regulate mitogenic and metastatic processes in various (perhaps all) mammary tissues, resulting in maintenance of normalcy or in progression to cancer. The suggestion is based on the following lines of evidence and summarized in Fig. 8: (1) Breast tissue, like many other tissues, has a number of enzymes capable of catalyzing the conversion of $\mathrm{P}$ to various metabolites, which can be grossly grouped into $5 \alpha$-pregnanes and 4-pregnenes. (2) In breast tumor tissue and tumorigenic cell lines, $5 \alpha$-reductase activity and mRNA expression are significantly higher, whereas $3 \alpha$ - and $20 \alpha-H S O$ activities and mRNA expression are significantly lower than in normal breast tissue and 


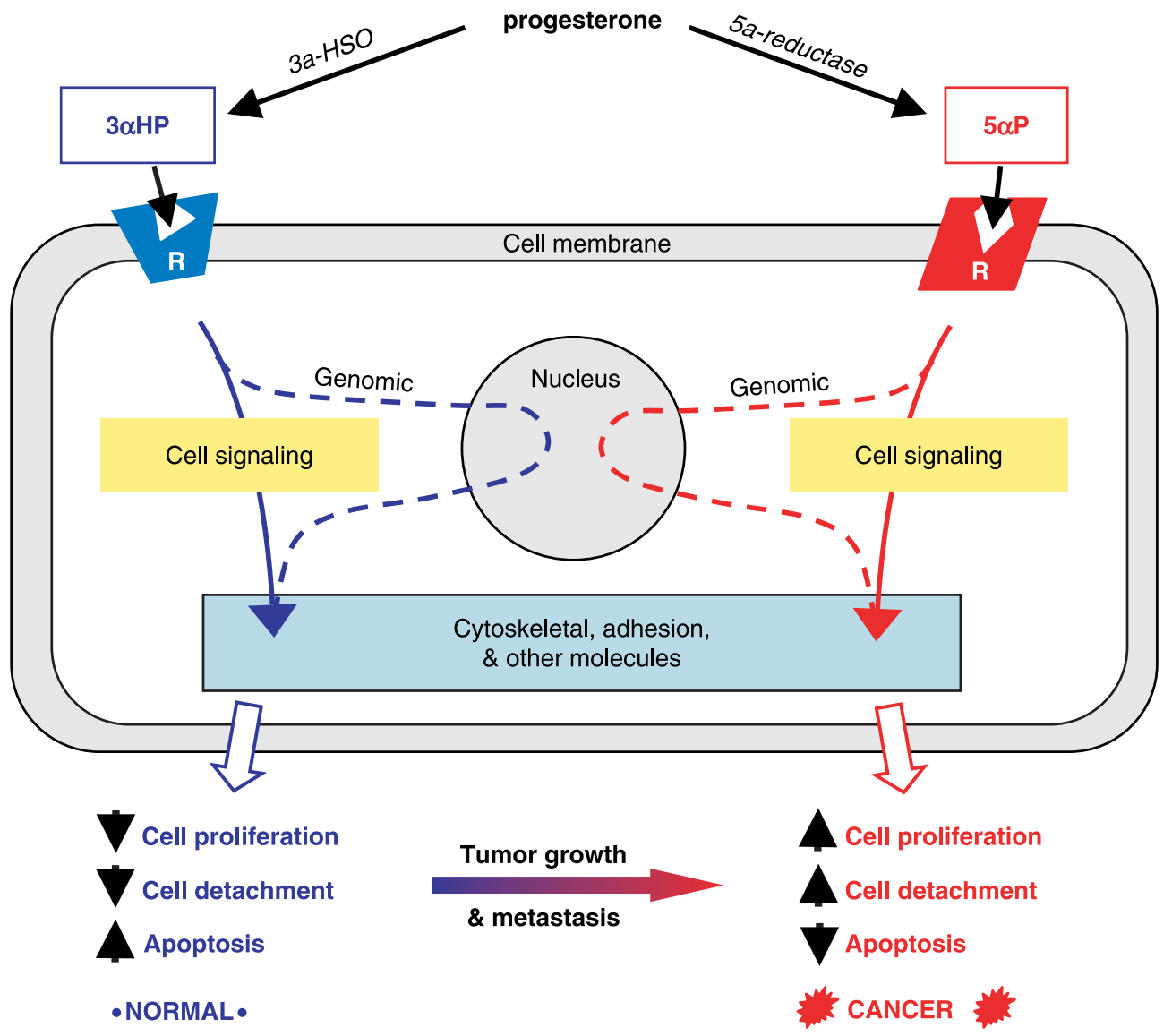

Figure 8 Summary of actions and action pathways of the progesterone metabolites $5 \alpha \mathrm{P}$ and $3 \alpha \mathrm{HP}$ in a stylized human breast cell and their proposed roles in maintaining normalcy or promoting cancer. Following binding to separate and specific receptors in the plasma membrane, $5 \alpha \mathrm{P}$ and $3 \alpha \mathrm{HP}$ act via cell signaling, and potentially indirectly via genomic, pathways to effect independent and opposite changes resulting in increases $(\uparrow)$ or decreases $(\downarrow)$ in cell proliferation, apoptosis and adhesion. Maintenance of normalcy depends on higher levels of $3 \alpha \mathrm{HP}$, and progression to neoplasia and metastasis are promoted by increased levels of $5 \alpha \mathrm{P}$.

nontumorigenic cells. (3) The result is that in para- and intra-cell environments of localized regions of the breast, the levels of $5 \alpha$-pregnanes such as $5 \alpha \mathrm{P}$ are increased, whereas those of the 4-pregnenes like $3 \alpha \mathrm{HP}$ are decreased. (4) Studies using various breast cell lines have shown that $5 \alpha \mathrm{P}$ and $3 \alpha \mathrm{HP}$ have opposing actions in terms of cell proliferation and adhesion; $5 \alpha \mathrm{P}$ stimulates cell proliferation (through increased mitosis and decreased apoptosis) and cell detachment, whereas $3 \alpha \mathrm{HP}$ suppresses cell proliferation (through decreased mitosis and increased apoptosis) and detachment. (5) Separate mechanisms of action of $5 \alpha \mathrm{P}$ and $3 \alpha \mathrm{HP}$ are proposed, involving binding to separate, specific, and novel membrane receptors that are up- or downregulated by estradiol and the $\mathrm{P}$ metabolites and that are linked to cell signaling pathways which transcribe different effects on cytoskeletal and adhesion molecules. (6) Based on the in vitro results, the paracrine/ autocrine functions of $5 \alpha \mathrm{P}$ are cancer-promoting and those of $3 \alpha \mathrm{HP}$ are cancer-inhibiting. Changes from normal status to progression through increasing degrees of neoplasia are determined by changes in the relative concentrations of the pro- and anti-cancer hormones in the microenvironment. (7) As the P metabolites affect cell lines with various characteristic (ER/P-positive or -negative, tumorigenic or nontumorigenic, estrogensensitive or -insensitive), it is suggested that they may be general determinants of normalcy or cancer of the human mammary gland (Wiebe 2005). They may thus provide a new endocrine basis for the majority of human breast cancers that do not respond to ER-based therapy and also an alternate one for those that do.

The work on the potential role of $\mathrm{P}$ metabolites in promoting normalcy or cancer of the breast is in its infancy and a number of issues need to be addressed. First, all the observations summarized in this review about the effects/actions of the $\mathrm{P}$ metabolites were made in vitro on breast cell lines in culture. 
To substantiate the hypothesis that the $\mathrm{P}$ metabolites play a role in mammary cancer, it is necessary to demonstrate their effects in vivo. Such experiments would test the $\mathrm{P}$ metabolites, $5 \alpha \mathrm{P}$ and $3 \alpha \mathrm{HP}$, for their independent and combined effects on promotion or inhibition of growth of mammary tumors in mouse models resulting from human cell line inoculates and/or derived spontaneously or by chemical induction. Encouraging evidence that $\mathrm{P}$ metabolites can have similar effects in vivo and in vitro has come from a pilot experiment conducted by Drs $\mathrm{R}$ Schillaci and $\mathrm{P}$ Elizalde (NRC, Buenos Aires). They showed (personal communication) that $\mathrm{C} 4 \mathrm{HD}$ murine cells inoculated into BALB/c mice developed into substantial palpable tumors if treated with $5 \alpha \mathrm{P}(40 \mathrm{mg}$ depot). Tumor growth rate was about the same (or slightly higher) with $5 \alpha \mathrm{P}$ as with an equivalent dose of medroxyprogesterone acetate, a known tumor inducer in this model (Lanari et al. 1986). Secondly, in terms of potentially preventing, suppressing, or regressing breast tumors, more attention (both in vivo and in vitro) needs to be directed at the presumptive anti-cancer $\mathrm{P}$ metabolite, $3 \alpha \mathrm{HP}$, as well as $5 \alpha$-reductase inhibitors. Thirdly, the structural characterization of the novel receptors located in the cell membranes would help in understanding the molecular mechanisms of action and in turn provide a basis in designing $5 \alpha \mathrm{PR}$ binding antagonists and $3 \alpha \mathrm{HPR}$ agonists. Fourthly, more information is needed on the mechanisms of action and the involved cell signaling pathways, particularly for $3 \alpha \mathrm{HP}$. Fifthly, with respect to their metastatic potential, effects of the $\mathrm{P}$ metabolites on angiogenesis and cell-to-cell as well as cell-to-matrix interaction molecules need to be explored. Sixthly, the identification of factors that alter expression of $5 \alpha$-reductase and HSOs, resulting in changes in 5 $\alpha$-pregnane:4pregnene ratios, may give insight into processes that initiate deregulation of $\mathrm{P}$ metabolite balance.

In addition to raising the status of the $\mathrm{P}$ metabolites from waste products to active hormones and to providing an alternative endocrine-based hypothesis for human breast cancer, the findings suggest new biomarkers, diagnostic tests, and therapeutic regimens that may be applicable to both estrogen-sensitive and -insensitive normal and cancerous human breast tissues (Wiebe et al. 2005). Biomarkers and diagnostic tests might be based on measurements of $\mathrm{P}$ metabolite concentrations in nipple aspirates, changes in $5 \alpha$-reductase and HSO activities and gene expression, and/or $5 \alpha \mathrm{P}$ receptor concentrations in biopsies. Therapeutic regimens might involve (a) actively decreasing $5 \alpha \mathrm{P}$ and increasing $3 \alpha \mathrm{HP}$ by blocking $5 \alpha-$ reductase and stimulating $3 \alpha-\mathrm{HSO}$ activities and gene expression, (b) blocking the binding of $5 \alpha \mathrm{P}$ to its receptor, and (c) down-regulating $5 \alpha \mathrm{P}$ receptor and up-regulating $3 \alpha \mathrm{HP}$ receptor levels.

In light of the findings regarding the $\mathrm{P}$ metabolites in relation to breast cancer, it appears pertinent to stress the importance of the intra- and para-cellular metabonomic microenvironments generated by the cells and potentially responsible either for maintaining normalcy or for transition/progression to neoplasia. It would seem propitious to consider therapies for breast cancer to be applied directly to the affected tissues via local depots or targeted infusions rather than the whole-body-everytissue mode of current ingestion routes. Thus, it is hoped that the evidence presented in this review will stimulate further research into the potential roles of $\mathrm{P}$ metabolite hormones in breast cancer and generate new ideas for its control, regression, and prevention.

\section{Acknowledgements}

I thank Drs Evelyn Vingilis (Family Medicine), Ronald Hobkirk (Emeritus, Biochemistry), and Martin Kavaliers (Psychology), The University of Western Ontario, for reading and commenting on a draft of the manuscript. This work was supported by grants from The Susan G Komen Breast Cancer Foundation, Canadian Institutes of Health Research and Natural Sciences, and Engineering Research Council of Canada. The author declares that there is no conflict of interest that would prejudice the impartiality of this scientific work.

\section{References}

Allen WM 1930 Physiology of the corpus luteum, V the preparation and some chemical properties of progestin, a hormone of the corpus luteum which produces progestational proliferation. American Journal of Physiology $\mathbf{9 2}$ 174-188.

Allen WM 1970 Progesterone: how did the name originate? Southern Medical Journal 63 1151-1155.

Allen WM \& Corner GW 1929 Normal growth and implantation of embryos after very early ablation of the ovaries, under the influence of extracts of the corpus luteum. American Journal of Physiology 88 340-346.

Anderson TJ, Battersby S, King RJB, McPherson K \& Going JJ 1989 Oral contraceptive use influences resting breast proliferation. Human Pathology 20 1139-1144.

Anderson WA, Perotti ME, McManaway M, Lindsey S \& Eckberg WR 1984 Similarities and differences in the ultrastructure of two hormone-dependent and one independent human breast carcinoma grown in athymic nude 
mice: comparison with the rat DMBA-induced tumor and normal secretory mammocytes. Journal of Submicroscopic Cytology 16 673-690.

Andersson S, Bishop RW \& Russell DW 1989 Expression cloning and regulation of steroid $5 \alpha$-reductase, an enzyme essential for male sexual differentiation. Journal of Biological Chemistry 264 16249-16255.

Andersson T \& Rafter J 1990 Progesterone metabolism in the microsomal fraction of the testis, head kidney, and trunk kidney from the rainbow trout. General and Comparative Endocrinology 79 130-135.

Andriole GL, Humphrey P, Ray P, Gleave ME, Trachtenberg J, Thomas LN, Lazier CB \& Rittmaster RS 2004 Effect of the dual $5 \alpha$-reductase inhibitor dutasteride on markers of tumor regression in prostate cancer. The Journal of Urology 172 915-919.

Arici A, Marshburn PB, MacDonald PC \& Dombrowski RA 1999 Progesterone metabolism in human endometrial stromal and gland cells in culture. Steroids 64 530-534.

Atherden LM 1959 Progesterone metabolism; investigation of the products of metabolism with human liver in vitro. Biochemical Journal 71 411-415.

Balthazart J, Verheyen G, Schumacher M \& Decuypere E 1988 Changes in progesterone metabolism in the chicken hypothalamus during induced egg laying stop and molting. General and Comparative Endocrinology 72 282-295.

Beck C, Wolfe M, Murphy L \& Wiebe JP 1997 Acute, nongenomic actions of the gonadal and neural steroid, $3 \alpha-$ hydroxy-4-pregnen-20-one ( $3 \alpha \mathrm{HP})$, in FSH release, studied in perifused rat anterior pituitary cells. Endocrine 6 221-229.

Beling CG \& Cederqvist LL 1978 Progesterone metabolism in cultured amniotic fluid cells. International Journal of Gynaecology and Obstetrics 15 317-321.

Ben-Ze'ev A 1985 The cytoskeleton in cancer cells. Biochimica et Biophysica Acta 780 197-212.

Berliner DL \& Wiest WG 1956 The extra-hepatic metabolism of progesterone in rats. Journal of Biological Chemistry 221 449-459.

Bershadsky AD, Gluck U, Denisenko ON, Sklyarova TV, Spector I \& Ben-Ze'ev A 1995 The state of actin assembly regulates actin and vinculin expression by a feedback loop. Journal of Cell Science 108 1183-1193.

Bertics SJ, Bertics PJ, Clarke JL \& Karavolas HJ 1987 Distribution and ovarian control of progestin-metabolizing enzymes in various rat hypothalamic regions. Journal of Steroid Biochemistry 26 321-328.

Birrell SN, Bentel JM, Hickey TE, Ricciardelli C, Weger MA, Horsfall DJ \& Tilley WD 1995 Androgens induce divergent proliferative responses in human breast cancer cell lines. Journal of Steroid Biochemistry and Molecular Biology 52 459-467.

Boccuzzi G, Tamagno E, Brignardello E, Di Monaco M, Aragno M \& Danni O 1995 Growth inhibition of DMBAinduced rat mammary carcinomas by the antiandrogen flutamide. Journal of Cancer Research and Clinical Oncology 121 150-154.
Bradlow HL \& Sepkovic DW 2004 Steroids as procarcinogenic agents. Annals of the New York Academy of Sciences 1028 216-232.

Bramson HD, Hermann D, Batchelor KW, Lee FW, James MK \& Frye SV 1997 Unique preclinical characteristics of GG745, a potent dual inhibitor of 5AR. Journal of Pharmacology and Experimental Therapeutics $\mathbf{2 8 2}$ 1496-1502.

Braunsberg H, Coldham NG, Leake RE, Cowan SK \& Wong WR 1987 Action of a progesterone on human breast cancer cells: mechanism of growth stimulation and inhibition. European Journal of Cancer and Clinical Oncology 23 563-572.

Brown CT \& Nuttall MC 2003 Dutasteride: a new 5 $\alpha$ reductase inhibitor for men with lower urinary tract symptoms secondary to benign prostate hyperplasia. International Journal of Clinical Practice 57 705-709.

Bryson MJ \& Sweat ML 1967 Metabolism of progesterone in human proliferative endometrium. Endocrinology 81 729-734.

Bryson MJ \& Sweat ML 1969 Metabolism of progesterone in human myometrium. Endocrinology 84 1071-1075.

Butenandt A, Westphal U \& Hohlweg W 1934 Über das Hormon des Corpus luteum. Zeitschrift für Physiologische Chemie 227 84-98.

Canosa LF, Pozzi AG \& Ceballos NR 1998 Pregnenolone and progesterone metabolism by the testes of Bufo arenarum. Journal of Comparative Physiology 168 491-496.

Cappelletti V, Miodini P, Fioravanti L \& DiFronzo G 1995 Effect of progestin treatment on estradiol- and growth factor-stimulated breast cancer cell lines. Anticancer Research 15 2551-2556.

Chang L \& Karin M 2001 Mammalian MAP kinase signalling cascades. Nature 410 37-40.

Chatani F, Nonoyama T, Sudo K, Miyajima H, Takeyama M, Takatsuka D, Mori H \& Matsumoto K 1990 Stimulatory effect of luteinizing hormone on the development and maintenance of $5 \alpha$-reduced steroid-producing testicular interstitial cell tumors in Fischer 344 rats. Anticancer Research 10 337-342.

Clark CL \& Sutherland RL 1990 Progestin regulation of cellular proliferation. Endocrine Reviews 11 266-302.

Clark RV, Hermann DJ, Cunningham GR, Wilson TH, Morrill BB \& Hobbs S 2004 Marked suppression of dihydrotestosterone in men with benign prostatic hyperplasia by dutasteride, a dual $5 \alpha$-reductase inhibitor. Journal of Clinical Endocrinology and Metabolism 89 2179-2184.

Clarke R, Skaar T, Baumann K, Leonessa F, James M, Lippman J, Thompson EW, Freter C \& Brunner N 1994 Hormonal carcinogenesis in breast cancer: cellular and molecular studies of malignant progression. Breast Cancer Research and Treatment 31 237-248.

Clevenger CV \& Plank TL 1997 Prolactin as an autocrine/paracrine factor in breast tissue. Journal of Mammary Gland Biology and Neoplasia 2 59-68. 
Cohen SM \& Ellwein LB 1990 Cell proliferation in carcinogenesis. Science 249 1007-1011.

Collins JA \& Jewkes DM 1974 Progesterone metabolism in adenocarcinoma of the endometrium. American Journal of Obstetrics and Gynecology 120 779-784.

Croxtall JD, Choudhury Q \& Flower RJ 2000 Glucocorticoids act within minutes to inhibit recruitment of signalling factors to activated EGF receptors through a receptordependent, transcription-independent mechanism. British Journal of Pharmacology 130 289-298.

Das R \& Vonderhaar BK 1997 Prolactin as a mitogen in mammary cells. Journal of Mammary Gland Biology and Neoplasia 2 29-39.

Desgres J, Frelin C \& Padieu P 1980 Progesterone metabolism in newborn rat heart cell cultures. Advances in Myocardiology 1 339-344.

Dhanvantari S \& Wiebe JP 1994 Suppression of folliclestimulating hormone by the gonadal- and neurosteroid, $3 \alpha$-hydroxy-4-pregnen-20-one involves actions at the level of the gonadotrope membrane/calcium channel. Endocrinology 134 371-376.

Di Monaco M, Leonardi L, Gatto V, Gallo M, Brignardello E \& Boccuzzi G 1995 Dihydrotestosterone affects the growth of hormone-unresponsive breast cancer cells: an indirect action. Anticancer Research 15 2581-2584.

Dinsdale CJ, Mirza FM \& Wiebe JP 1992 Glycerol alters cytoskeleton and cell adhesion while inhibiting cell proliferation. Cell Biology International Reports 16 591-602.

Dorfman RI 1954 In vivo metabolism of neutral steroid hormones. Journal of Clinical Endocrinology and Metabolism 14 318-325.

Eechaute W, de Thibault de Boesinghe L \& Lacroix E 1983 Steroid metabolism and steroid receptors in dimethylbenz(a)anthracene-induced rat mammary tumors. Cancer Research 43 4260-4265.

Fennessey PV, Pike AW, Gonzalez-Aller C \& Horwitz KB 1986 Progesterone metabolism in T47Dco human breast cancer cells-I, $5 \alpha$-pregnan-3 $\beta, 6 \alpha$-diol-20-one is the secreted product. Journal of Steroid Biochemistry 25 (5A) 641-648.

Ferguson MM \& Bannon AM 1983 Progesterone metabolism in the murine submandibular salivary gland. Journal of Dental Research 62 1031-1032.

Fotherby K 1996 Bioavailability of orally administered sex steroids used in oral contraception and hormone replacement therapy. Contraception 54 59-69.

Frost P, Gomez EC, Weinstein GO, Lamas J \& Hsia SL 1969 Metabolism of progesterone-4- ${ }^{14} \mathrm{C}$ in vitro in human skin and vaginal mucosa. Biochemistry 8 948-952.

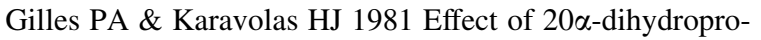
gesterone, progesterone, and their $5 \alpha$-reduced metabolites on serum gonadotropin levels and hypothalamic LHRH content. Biology of Reproduction 24 1088-1097.

Gingras S, Morrigl R, Groner B \& Simard J 1999 Induction of $3 \beta$-hydroxysteroid dehydrogenase $/ \Delta^{5}-\Delta^{4}$ isomerase type 1 gene transcription in human breast cancer cell lines and in normal mammary epithelial cells by interleukin-4 and interleukin-13. Molecular Endocrinology 13 66-81.
Glasier MA, Wiebe JP \& Hobkirk R 1994 Progesterone metabolism by guinea pig intrauterine tissues. Journal of Steroid Biochemistry and Molecular Biology 51 199-207.

Going JJ, Anderson TJ, Battersby S \& MacIntyre CCA 1988 Proliferative and secretory activity in human breast during natural and artificial menstrual cycles. American Journal of Pathology 130 193-204.

Groshong SD, Owen GI, Grimison B, Schauer IE, Todd MC, Langan TA, Sclafani RA, Lange CA \& Horwitz KB 1997 Biphasic regulation of breast cancer cell growth by progesterone: role of the cyclin-dependent kinase inhibitors, p21 and p27Kip1. Molecular Endocrinology 11 1593-1607.

Hackenberg R, Luttchens S, Hofman J, Kunzmann R, Holzel F \& Schulz KD 1991 Androgen sensitivity of the new human breast cancer cell line MFM-223. Cancer Research 51 5722-5727.

Hammond GL, Abrams LS, Creasy GW, Natarajan J, Allen JG \& Siiteri PK 2003 Serum distribution of the major metabolites of norgestimate in relation to its pharmacological properties. Contraception 67 93-99.

Hanahan D \& Weinberg RA 2000 The hallmarks of cancer. Cell 100 57-70.

Hanukoglu I, Karavolas HJ \& Goy RW 1977 Progesterone metabolism in the pineal, brain stem, thalamus and corpus callosum of the female rat. Brain Research 125 313-324.

Helige C, Zellnig G, Hoffman-Wellenhof R, Fink-Puches R, Smolle J \& Tritthart HA 1997 Interrelation of motility, cytoskeletal organization and gap junctional communication with invasiveness of melanocyte cells in vitro. Invasion and Metastasis 17 26-41.

Henzl MR 2001 Norgestimate. From the laboratory to three clinical indications. Journal of Reproductive Medicine 46 647-661.

Hobkirk R, Glasier MA \& Wong M 1997 The effect of chorion-uterine interaction upon free progesterone metabolism during advanced gestation in the guinea pig. Journal of Steroid Biochemistry and Molecular Biology 62 185-193.

Holme TC 1990 Cancer cell structure: actin changes in tumour cells - possible mechanisms for malignant tumour formation. European Journal of Surgery and Oncology 16 161-169.

Holth LT, Chadee DN, Spencer VA, Samuel SK, Safneck JR \& Davie JR 1998 Chromatin, nuclear matrix and the cytoskeleton: role of cell structure in neoplastic transformation. International Journal of Oncology 13 827-837.

Horwitz KB, Costlow ME \& McGuire WL 1975 MCF-7; a human breast cancer cell line with estrogen, androgen, progesterone, and glucocorticoid receptors. Steroids $\mathbf{2 6}$ 785-795.

Horwitz KB, Wei LL, Sedlacek SM \& D'Arville CN 1985 Progestin action and progesterone receptor structure in human breast cancer: a review. Recent Progress in Hormone Research 41 249-316.

Horwitz KB, Pike AW, Gonzalez-Aller C \& Fennessey PV 1986 Progesterone metabolism in T47Dco human breast 
cancer cells-II, Intracellular metabolic path of progesterone and synthetic progestins. Journal of Steroid Biochemistry 25 911-916.

Humphries MJ \& Newham P 1998 The structure of cell adhesion molecules. Trends in Cell Biology 8 78-83.

Iczkowski KA, Qiu J, Qian J, Somerville MC, Rittmaster RS, Andriole GL \& Bostwick DG 2005 The dual 5 $\alpha$-reductase inhibitor dutasteride induces atrophic changes and decreases relative cancer volume in human prostate. Urology 65 76-82.

Jabara AG 1967 Effects of progesterone on 9,10-dimethyl1,2-benzanthracene-induced mammary tumours in Sprague-Dawley rats. British Journal of Cancer 21 418-429.

Ji Q, Chang L, VanDenBerg D, Stanczyk FZ \& Stolz A 2003 Selective reduction of AKR1C2 in prostate cancer and its role in DHT metabolism. The Prostate 54 275-289.

Ji Q, Aoyama C, Nien YD, Liu PI, Chen PK, Chang L, Stanczyk FZ \& Stolz A 2004 Selective loss of AKR1C1 and AKR1C2 in breast cancer and their potential effect on progesterone signaling. Cancer Research 64 7610-7617.

Kandouz M, Lombert A, Perrot JY, Jacob D, Carvajal S, Kazem A, Rostene W, Therwath A \& Gompel A 1999 Proapoptotic effects of antiestrogens, progestins and androgen in breast cancer cells. Journal of Steroid Biochemistry and Molecular Biology 69 463-471.

Kavaliers M \& Wiebe JP 1987 Analgesic effects of the progesterone metabolite, $3 \alpha$-hydroxy-5 $\alpha$-pregnan-20one, and possible modes of action in mice. Brain Research 415 393-398.

Keshamouni VG, Mattingly RR \& Reddy KB 2002 Mechanism of 17- $\beta$-Estradiol-induced Erk1/2 activation in breast cancer cells. Journal of Biological Chemistry 277 22558-22565.

King RJB 1993 Estrogen and progestin effects in human breast carcinogenesis. Breast Cancer Research and Treatment 27 3-15.

Korneyev A, Guidotti A \& Costa E 1993 Regional and interspecies differences in brain progesterone metabolism. Journal of Neurochemistry 61 2041-2047.

Kuhl H 1996 Comparative pharmacology of newer progestogens. Drugs 51 188-215.

Kuwata M, Yamada M, Tamai M, Kitamura Y \& Matsumoto K 1976 Progesterone metabolism in vitro by testes from germ cell-free mice of different ages. Biochimica et Biophysica Acta 486 127-135.

de la Llosa-Hermier MP, Leboulleux P, Chene N \& Martal J 1983 Inhibitory effect of ovine and human placental lactogens on progesterone catabolism in luteinized rat ovaries in vitro. Placenta 4 479-487.

Lacy LR, Knudson MM, Williams JJ, Richards JS \& Midgley AR Jr 1976 Progesterone metabolism by the ovary of the pregnant rat: discrepancies in the catabolic regulation model. Endocrinology 99 929-934.

Laduron PM 1984 Criteria for receptor sites in binding studies. Biochemical Pharmacology 33 833-839.

Laine M \& Ojanotko-Harri A 1990 Progesterone metabolism by major salivary glands of rat-I, Submandibular and sublingual glands. Journal of Steroid Biochemistry 35 723-728.

Laine MA \& Ojanotko AO 1999 Progesterone metabolism in human saliva in vitro. Journal of Steroid Biochemistry and Molecular Biology 70 109-113.

Lanari C, Molinolo AA \& Pasqualini CD 1986 Induction of mammary adenocarcinomas by medroxyprogesterone acetate in BALB/c female mice. Cancer Letters $\mathbf{3 3}$ 215-223.

Lapointe J \& Labrie C 2001 Role of the cyclin-dependent kinase inhibitor p27(Kip1) in androgen-induced inhibition of CAMA-1 breast cancer cell proliferation. Endocrinology 142 4331-4338.

Lewis MJ, Wiebe JP \& Heathcote JG 2004 Expression of progesterone metabolizing enzyme genes (AKR1C1, AKR1C2, AKR1C3, SRD5A1, SRD5A2) is altered in human breast carcinoma. (http://www.biomedcentral. com/1471-2407/4/27) BMC Cancer 4 (27) 1-12.

Limbird LE 1996 Identification of receptors using direct radioligand techniques. In Cell Surface Receptors: A Short Course on Theory and Methods. edn 2. Norwell, MA: Klewer Academic Publishers.

Little B, diMartinis J \& Nyholm B 1959 The conversion of progesterone to delta 4 pregnene-20 alpha-ol, 3-one by human placenta in vitro. Acta Endocrinologica (Copenh) 30 530-538.

Lloyd RV 1979 Studies on the progesterone receptor content and steroid metabolism in normal and pathological human breast tissues. Journal of Clinical Endocrinology and Metabolism 48 585-593.

Luna EJ \& Hitt AL 1992 Cytoskeleton-plasma membrane interactions. Science 258 955-964.

Luo S, Stojanovic M, Labrie C \& Labrie F 1997 Inhibitory effect of the novel anti-estrogen EM-800 and medroxyprogesterone acetate on estrone-stimulated growth of dimethylbenz $[a]$ anthracene-induced mammary carcinoma in rats. International Journal of Cancer $\mathbf{7 3}$ 580-586.

Majewska MD, Harrison NL, Schwartz RD, Barber JL \& Paul SM 1986 Steroid hormone metabolites are barbiturate-like modulators of the GABA receptor. Science $\mathbf{2 3 2}$ 1004-1007.

Marrone BL 1986 Ovarian steroidogenesis in vitro during the first month posthatching in the domestic chick: gonadotropin responsiveness and $\left[{ }^{3} \mathrm{H}\right]$ progesterone metabolism. General and Comparative Endocrinology 62 62-69.

Marrone BL \& Karavolas HJ 1981 Progesterone metabolism by the hypothalamus, pituitary, and uterus of the rat during pregnancy. Endocrinology 109 41-45.

Marrone BL \& Karavolas HJ 1982 Progesterone metabolism by the hypothalamus, pituitary, and uterus of the aged rat. Endocrinology 111 162-167.

Martini L, Melcangi RC \& Maggi R 1993 Androgen and progesterone metabolism in the central and peripheral nervous system. Journal of Steroid Biochemistry and Molecular Biology 47 195-205. 
Matsumoto K, Yamada M \& Tsujimura T 1976 Progesterone metabolism in vitro by rabbit testes at different stages of development. Endocrinology 99 1269-1272.

Matsunaga M, Okuhara K, Ukena K \& Tsutsui K 2004 Identification of $3 \beta, 5 \beta$-tetrahydroprogesterone, a progesterone metabolite, and its stimulatory action on preoptic neurons in the avian brain. Brain Research 1007 160-616.

Mauvais-Jarvis P, Baudot N \& Bercovici JP 1969 In vivo studies on progesterone metabolism by human skin. Journal of Clinical Endocrinology and Metabolism 29 1580-1585.

McGuire WL 1987 Prognostic factors for recurrence and survival in human breast cancer. Breast Cancer Research and Treatment 10 5-9.

McGuire WL \& Horwitz KB 1977 A role for progesterone in breast cancer. Annals of the New York Academy of Sciences 286 90-100.

Melcangi RC, Celotti F \& Martini L 1994 Progesterone 5 $\alpha$ reduction in neuronal and in different types of glial cell cultures: type 1 and 2 astrocytes and oligodendrocytes. Brain Research 639 202-206.

Milewich L, Gant NF, Schwarz BE, Prough RA, Chen GT, Athey B \& MacDonald PC 1977 Initiation of human parturition, VI. Identification and quantification of progesterone metabolites produced by the components of human fetal membranes. Journal of Clinical Endocrinology and Metabolism 45 400-411.

Miller WR 1990 Pathways of hormone metabolism in normal and non-neoplastic breast tissue. Annals of the New York Academy of Sciences 586 53-59.

Minjarez D, Konda V \& Word RA 2001 Regulation of uterine $5 \alpha$-reductase type 1 in mice. Biology of Reproduction 65 1378-1382.

Mol JA, van Garderen E, Rutteman GR \& Rijnberk A 1996 New insights in the molecular mechanism of progestininduced proliferation of mammary epithelium: induction of the local biosynthesis of growth hormone $(\mathrm{GH})$ in the mammary gland of dogs, cats and humans. Journal of Steroid Biochemistry and Molecular Biology 57 67-71.

Moon YS, Duleba AJ, Kim KS \& Yuen BH 1986 Effects of prostaglandins E2 and F2 alpha on progesterone metabolism by rat granulosa cells. Biochemical and Biophysical Research Communications 135 764-769.

Moon YS, Duleba AJ \& Yuen BH 1987 Time-dependent effects of follicle-stimulating hormone on progesterone metabolism by cultured rat granulosa cells. Biochemical and Biophysical Research Communications 144 67-73.

Mori M \& Tamaoki B 1980 In vitro metabolism of progesterone in the mammary tumour and the normal mammary gland of GRS/A strain of mice and dependency of some steroidmetabolizing enzyme activities upon ovarian function. European Journal of Cancer 16 185-193.

Mori M, Tominaga T \& Tamaoki B 1978 Steroid metabolism in the normal mammary gland and in the dimethylbenzthracene-induced mammary tumour of rats. Endocrinology 102 1387-1397.
Musgrove EA \& Sutherland RL 1994 Cell cycle control by steroid hormones. Seminars in Cancer Biology 5 381-389.

Nakajima T, Yasuda K, Nishizawa M, Okada H, Yoshimura T, Ito S \& Kanzaki H 2003 Expression of $20 \alpha-$ hydroxysteroid dehydrogenase mRNA in human endometrium and decidua. Endocrine Journal 50 105-111.

Nimrod A 1977 Studies on the synergistic effect of androgen on the stimulation of progestin secretion by FSH in cultured rat granulosa cells: progesterone metabolism and the effect of androgens. Molecular and Cellular Endocrinology 8 189-199.

Ortmann J, Prifti S, Bohlmann MK, Rehberger-Schneider S, Strowitzki T \& Rabe T 2002 Testosterone and 5 $\alpha$ dihydrotestosterone inhibit in vitro growth of human breast cancer cell lines. Gynecological Endocrinology 16 113-120.

Patte-Mensah C, Kibaly C \& Mensah-Nyagan AG 2005 Substance $\mathrm{P}$ inhibits progesterone conversion to neuroactive metabolites in spinal sensory circuit: a potential component of nociception. PNAS 102 9044-9049.

Pawlak KJ \& Wiebe JP 2005 Regulation of estrogen receptor (ER) levels in MCF-7 cells by progesterone metabolites. The Endocrine Society 87th Annual Meeting, San Diego, 2005. Abstract.

Pawlak KJ, Zhang G \& Wiebe JP 2005 Membrane 5 $\alpha$ pregnane-3,20-dione $(5 \alpha \mathrm{P})$ receptors in $\mathrm{MCF}-7$ and $\mathrm{MCF}$ $10 \mathrm{~A}$ breast cancer cells are up-regulated by estradiol and $5 \alpha \mathrm{P}$ and down-regulated by the progesterone metabolites, $3 \alpha$-dihydroprogesterone and $20 \alpha$-dihydroprogesterone, with associated changes in cell proliferation and detachment. Journal of Steroid Biochemistry and Molecular Biology 97 278-288.

Pearson G, Robinson F, Beers GT, Xu B, Karandikar M, Berman K \& Cobb MH 2001 Mitogen-activated protein (MAP) kinase pathways: regulation and physiological functions. Endocrine Reviews 22 153-183.

Perlman D, Jackson PW, Giuffre N \& Fried J 1960 Metabolism of progestereone and testosterone by mammalian cells growing in suspension culture. Canadian Journal of Biochemistry and Physiology 38 393-395.

Pignataro L, Lerner AA, Baranao JL \& de Plazas SF 1998 Biosynthesis of progesterone derived neurosteroids by developing avian CNS: in vitro effects on the GABAA receptor complex. International Journal of Developmental Neuroscience 16 433-441.

Pike MC, Spicer DV, Dahmoush L \& Press MF 1993 Estrogens, progestogens, normal breast cell proliferation, and breast cancer risk. Epidemiologic Reviews 15 17-35.

Pollow K, Lubbert H, Boquoi E \& Pollow B 1975 Progesterone metabolism in normal human endometrium during the menstrual cycle and in endometrial carcinoma. Journal of Clinical Endocrinology and Metabolism 41 729-737.

Pomata PE, Colman-Lerner AA, Baranao JL \& Fiszman ML 2000 In vivo evidences of early neurosteroid synthesis in the developing rat central nervous system and placenta. Brain Research Developmental Brain Research 120 83-86. 
Potten CS, Watson RJ, Williams GT, Tickle S, Roberts SA, Harris M \& Howel A 1988 The effect of age and menstrual cycle upon proliferative activity of the normal human breast. British Journal of Cancer $\mathbf{5 8}$ 163-170.

Poulin R, Baker D \& Labrie F 1988 Androgens inhibit basal and estrogen-induced cell proliferation in the ZR-75-1 human breast cancer cell line. Breast Cancer Research and Treatment 12 213-225.

Purves-Tyson TD \& Keast JR 2004 Rapid actions of estradiol on cyclic AMP response-element binding protein phosphorylation in dorsal root ganglion neurons. Neuroscience 129 629-637.

Raz A 1988 Adhesive properties of metastasizing tumor cells. Ciba Foundation Symposia 141 109-122.

Redmond AF \& Pepe GJ 1986 Uterine progesterone metabolism during early pseudopregnancy in the rat. Biology of Reproduction 35 949-955.

Rhodes ME \& Frye CA 2001 Inhibiting progesterone metabolism in the hippocampus of rats in behavioral estrus decreases anxiolytic behaviors and enhances exploratory and antinociceptive behaviors. Cognitive, Affective and Behavioral Neuroscience 1 287-296.

Sadano H, Inoue M \& Taniguchi S 1992 Differential expression of vinculin between weakly and highly metastatic B16-melanoma cell lines. Japanese Journal of Cancer Research 83 625-630.

Santen RJ, Manni H, Harvey H \& Redmond C 1990 Endocrine treatment of breast cancer in women. Endocrine Reviews 11 221-265.

Santen RJ, Song RX, McPherson R, Kumar R, Adam L, Jeng M-H \& Yue W 2002 The role of mitogen-activated protein (MAP) kinase in breast cancer. Journal of Steroid Biochemistry and Molecular Biology 80 239-256.

Savard K, Dorfman RI, Baggett B \& Engel LL 1956 Biosynthesis of androgens from progesterone by human testicular tissue in vitro. Journal of Clinical Endocrinology and Metabolism 16 1629-1630.

Schliwa M, Nakamura T, Porter KR \& Euteneuer U 1984 A tumor promoter induces rapid and coordinated reorganization of actin and vinculin in cultured cells. Journal of Cell Biology 99 1045-1059.

Schroeder MD, Cymowicz J \& Schuler LA 2002 Prolactin modulates cell cycle regulators in mammary tumor epithelial cells. Molecular Endocrinology 16 45-57.

Seamark RF, Nancarrow CD \& Gardiner J 1970 Progesterone metabolism in ovine blood: the formation of $3 \alpha$-hydroxypregn-4-en-20-one and other substances. Steroids 15 589-604.

Segaloff A 1975 Steroids and carcinogenesis. Journal of Steroid Biochemistry 6 171-175.

Selye H 1942 Correlations between the chemical structure and the pharmacological actions of the steroids. Endocrinology 30 437-453.

Sheldrick EL, Ricketts AP \& Flint AP 1981 Placental production of $5 \beta$-pregnane-3 $\alpha, 20 \alpha$-diol in goats. Journal of Endocrinology 90 151-158.
Shyamala G, Chou YC, Louie SG, Guzman RC, Smith GH \& Nandi S 2002 Cellular expression of estrogen and progesterone receptors in mammary glands: regulation by hormones, development and aging. Journal of Steroid Biochemistry and Molecular Biology 80 137-148.

Simoncini T, Mannella P, Fornari L, Caruso A, Varone G \& Genazzani AR 2004 Genomic and non-genomic effects of estrogens on endothelial cells. Steroids 69 537-542.

Sitruk-Ware R 2004 Pharmacological profile of progestins. Maturitas 47 277-283.

Slaunwhite WR Jr \& Samuels LT 1956 Progesterone as a precursor of testicular androgens. Journal of Biological Chemistry 220 341-352.

Slotta KH, Ruschig H \& Fels E 1934 Reindarstellung der Hormone aus dem Corpus-Luteum. Berichte der Deutschen Chemischen Gesellschaft 67 1270-1273.

Soto AM, Murai JT, Siiteri PK \& Sonnenschein C 1986 Control of cell proliferation: evidence for negative control on estrogen-sensitive T47D human breast cancer cells. Cancer Research 46 2271-2275.

Soule HD, Maloney TM, Wolman SR, Peterson WD Jr, Brenz R, McGrath CM, Russo J, Pauley RJ, Jones RF \& Brooks SC 1990 Isolation and characterization of a spontaneously immortalized human breast epithelial cell line, MCF-10. Cancer Research 50 6075-6086.

Sporn MB 1996 The war on cancer. Lancet 347 1377-1381.

Stegner HE \& Lisboa BP 1984 Steroid metabolism in an androblastoma (Sertoli-Leydig cell tumor): a histopathological and biochemical study. International Journal of Gynecological Pathology 2 410-425.

Stuerenburg HJ, Fries U, Iglauer F \& Kunze K 1997 Effect of age on synthesis of the GABAergic steroids 5- $\alpha$ pregnane-3,20-dione and 5- $\alpha$-pregnane-3- $\alpha$-ol-20-one in rat cortex in vitro. Journal of Neural Transmission 104 249-257.

Sugino N, Telleria CM \& Gibori G 1997 Progesterone inhibits $20 \alpha$-hydroxysteroid dehydrogenase expression in the rat corpus luteum through the glucocorticoid receptor. Endocrinology 138 4497-4500.

Suzuki H, Nagata H, Shimada Y \& Konno A 1998 Decrease in gamma-actin expression, disruption of actin microfilaments and alterations in cell adhesion systems associated with acquisition of metastatic capacity in human salivary gland adenocarcinoma cell clones. International Journal of Oncology 12 1079-1084.

Suzuki T, Darnel AD, Akahira J-I, Ariga N, Ogawa S, Kaneko C, Takeyama J, Moriya T \& Sasano H 2001 5aReductases in human breast carcinoma: possible modulator of in situ androgenic actions. Journal of Clinical Endocrinology and Metabolism 86 2250-2257.

Sweat ML, Berliner DL, Bryson MJ, Nabo RSC Jr, Haskell J \& Holmstrom EG 1960 The synthesis and metabolism of progesterone in the human and bovine ovary. Biochimica et Biophysica Acta 40 289-296.

Thompson CB 1995 Apoptosis in the pathogenesis and treatment of disease. Science 267 1456-1462. 
Tilbe KS \& Wiebe JP 1981 Sertoli cell capacity to metabolize progesterone: variation with age and the effect of folliclestimulating hormone. Endocrinology 108 597-604.

Turgeon C, Gingras T, Carriere M-C, Blais Y, Labrie F \& Simard J 1998 Regulation of sex steroid formation by interleukin-4 and interleukin-6 in breast cancer cells. Journal of Steroid Biochemistry and Molecular Biology 6 $151-162$.

Ukena K, Honda Y, Lea RW \& Tsutsui K 2001 Developmental changes in progesterone biosynthesis and metabolism in the quail brain. Brain Research 898 190-194.

Vanderbilt JN, Miesfeld R, Maler BA \& Yamamoto KR 1987 Intercellular receptor concentration limits glucocorticoid-dependent enhancer activity. Molecular Biology 1 68-74.

Watson CS, Norfleet AM, Pappas TC \& Gametchu B 1999 Rapid actions of estrogens in GH3/B6 pituitary tumor cells via a plasma membrane version of estrogen receptor- $\alpha$. Steroids 64 5-13.

Webb P, Lopez GN, Greene GL, Baxter JD \& Kushner PJ 1992 The limits of the cellular capacity to mediate an estrogen response. Molecular Endocrinology 6 157-167.

Wehling M 1997 Specific, nongenomic actions of steroid hormones. Annual Review of Physiology 59 365-395.

Weiler PJ \& Wiebe JP 2000 Plasma membrane receptors for the cancer-regulating progesterone metabolites, $5 \alpha$ pregnane-3,20-dione and 3 $\alpha$-hydroxy-4-pregnen-20-one in MCF-7 breast cancer cells. Biochemical and Biophysical Research Communications 272 731-737.

Welsh CW 1982 Hormones and murine mammary tumorigenesis: an historical view. In Hormonal Regulation of Mammary Tumors, pp. 1-29. Ed BS Leung. Montreal, Canada: Eden Press.

Wiebe JP 1978 Isolated Sertoli cells from immature rats produce $20 \alpha$-hydroxy-pregn-4-en-3-one from progesterone and $5 \alpha$-pregnane-3 $\beta, 20 \alpha$-diol from pregnenolone. Biochemical and Biophysical Research Communications 84 1003-1008.

Wiebe JP 1997 Nongenomic actions of steroids on gonadotropin release. Recent Progress in Hormone Research 52 71-101.

Wiebe JP 2005 Role of progesterone metabolites in mammary cancer. Journal of Dairy Research 72 51-57.

Wiebe JP \& Tilbe KS 1979 De novo synthesis of steroids (from acetate) by isolated rat Sertoli cells. Biochemical and Biophysical Research Communications 89 1107-1113.

Wiebe JP \& Kavaliers M 1988 Analgesic effects of the putative FSH- suppressing gonadal steroid, $3 \alpha$-hydroxy4-pregnen-20-one: possible modes of action. Brain Research 461 150-157.

Wiebe JP \& Muzia D 2001 The endogenous progesterone metabolite, $5 \alpha$-pregnene-3,20-dione, decreases cell-substrate attachment, adhesion plaques, vinculin expression, and polymerized F-actin in MCF-7 breast cancer cells. Endocrine 16 7-14.

Wiebe JP \& Lewis MJ 2003 Activity and expression of progesterone metabolizing $5 \alpha$-reductase, $20 \alpha$ - hydroxysteroid oxidoreductase and $3 \alpha(\beta)$-hydroxysteroid oxidoreductases in tumorigenic (MCF-7, MDA-MB-231, T-47D) and nontumorigenic (MCF-10A) human breast cancer cells. (http://www.biomedcentral.com/1471-2407/ 3/9). BMC Cancer 3 (9) 1-15.

Wiebe JP, Tilbe KS \& Buckingham KD 1980 An analysis of the metabolites of progesterone produced by isolated Sertoli cells at the onset of gametogenesis. Steroids 35 561-577.

Wiebe JP, Myers KI \& Auersperg N 1987 Modification of steroidogenesis in rat adrenocortical cells transformed by Kirsten Murine Sarcoma virus. Cancer Research 47 1325-1332.

Wiebe JP, Buckingham KD, Zobell RL \& Hertelendy F 1990 Metabolism of progesterone by avian granulosa cells in culture. Journal of Steroid Biochemistry and Molecular Biology 37 113-120.

Wiebe JP, Barr KJ \& Buckingham KD 1991 A radioimmunoassay for the regulatory allylic steroid, $3 \alpha-$ hydroxy-4-pregnen-20-one ( $3 \alpha \mathrm{HP})$. Journal of Steroid Biochemistry and Molecular Biology 38 505-512.

Wiebe JP, de Gannes GC \& Dallaire MJ 1994a Synthesis of the allylic regulatory steroid, 3 $\alpha$-hydroxy-4-pregnen-20one, by rat granulosa cells and its regulation by gonadotropins. Biology of Reproduction 50 956-964.

Wiebe JP, Dhanvantari S, Watson PH \& Huang Y $1994 b$ Suppression in gonadotropes of gonado-tropin-releasing hormone-stimulated follicle-stimulating hormone release by the gona-dal- and neurosteroid, $3 \alpha$-hydroxy-4-pregnen20-one involves cytosolic calcium. Endocrinology 134 377-382.

Wiebe JP, Boushy D \& Wolfe M 1997 Synthesis, metabolism and levels of the neuroactive steroid, 3a-hydroxy-4pregnen-20-one ( $3 \alpha \mathrm{HP})$, in rat pituitaries. Brain Research 764 158-166.

Wiebe JP, Muzia D, Hu J, Szwajcer D, Hill SA \& Seachrist JL 2000 The 4-pregnene and $5 \alpha$-pregnane progesterone metabolites formed in non-tumorous and tumorous breast tissue have opposite effects on breast cell proliferation and adhesion. Cancer Research 60 936-943.

Wiebe JP, Zhang G \& Woodford SD 2004 The progesterone metabolites, $5 \alpha$-dihydroprogesterone $(5 \alpha \mathrm{P})$ and $3 \alpha$-hydroxy-4-pregnen-20-one ( $3 \alpha \mathrm{HP})$, have opposing effects on cell substrate adhesion, amount of polymerized actin and adhesion plaque-associated vinculin in MCF-7, MCF-10A, MDA-MB-231 and T47D breast cell lines. The Endocrine Society 86th Annual Meeting, New Orleans, 2004. Abstract.

Wiebe JP, Lewis MJ, Cialacu V, Pawlak KJ \& Zhang G 2005 The role of progesterone metabolites in breast cancer: potential for new diagnostics and therapeutics.

Journal of Steroid Biochemistry and Molecular Biology 93 201-208.

Wiebe JP, Souter L \& Zhang G 2006 Dutasteride affects progesterone metabolizing enzyme activity/expression in human breast cell lines resulting in suppression of cell proliferation and detachment. Journal of Steroid Biochemistry and Molecular Biology 100 In press. 
Wiest WG 1956 The metabolism of progesterone to delta4pregnen-20 $\alpha$-ol-3-one in eviscerated female rats. Journal of Biological Chemistry 221 461-467.

Wilkins JA \& Lin S 1982 High-affinity interaction of vinculin with actin filaments. Cell 28 83-90.

Wood PH \& Wiebe JP 1989 Selective suppression of FSH secretion in anterior pituitary cells in culture by the gonadal steroid, $3 \alpha$-hydroxy-4-pregnen-20-one ( $3 \alpha \mathrm{HP}$ ). Endocrinology 125 41-48.

Zhang G, Cialacu V, Wiebe JP 2005 Opposing effects of the progesterone metabolites, $5 \alpha$-pregnane-3,20-dione $(5 \alpha \mathrm{P})$ and $3 \alpha$-hydroxy-4-pregnen-20-one ( $3 \alpha \mathrm{HP}$ ) on apoptosis in MCF7 and T-47D breast cancer cells, The Endocrine Society 87th Annual Meeting, San Diego, 2005: Abstract \#P3-652, p 705.
Zhang J, Ming LJ, Sjovall J, Cook HW, Ridgway ND \& Byers DM 1999 Progesterone metabolism in human fibroblasts is independent of P-glycoprotein levels and Niemann-Pick type $\mathrm{C}$ disease. Journal of Steroid Biochemistry and Molecular Biology 70 123-131.

Zhong L, Parmer TG, Robertson MC \& Gibori G 1997 Prolactin-mediated inhibition of $20 \alpha$-hydroxysteroid dehydrogenase gene expression and the tyrosine kinase system. Biochemical and Biophysical Research Communications 235 587-592.

Zmigrod A, Lindner HR \& Lamprecht SA 1972 Reductive pathways of progesterone metabolism in the rat ovary. Acta Endocrinologica 69 141-152. 